\title{
Power Sources of Military Helicopters
}

\author{
Béla VARGA ${ }^{1}$
}

\begin{abstract}
In the early 1940s the first practically usable helicopters rose into the sky. Their importance was quickly recognised both by the military and civilian decision makers. A good summary of their most important advantage is the next quotation: "If you are in trouble anywhere in the world, an airplane can fly over and drop flowers, but a helicopter can land and save your life." (Igor Sikorsky, 1947) Just after their appearance it immediately became an urgent problem to replace the relatively low-power and heavy piston engines, for which the much lighter and more powerful turboshaft engines offered a good alternative. Significant improvement of helicopter engines, which has embodied mainly in power to weight ratio, thermal cycle efficiency, specific fuel consumption, together with reliability and maintainability, of course, has influenced the technicaltactical parameters of helicopters. In this paper I introduce the evolution of helicopter turboshaft engines, the most important manufacturers and engine types. Through statistical analysis I display what kind of performance parameters the helicopter turboshaft engines had in the past and have in the present days.
\end{abstract}

Keywords: helicopter gas turbine engines, turboshaft, shaft power, specific fuel consumption, thermal efficiency, specific net work output, specific power

\section{The Beginning of the Gas Turbine Era}

By the end of World War II, piston engine and propeller driven aircraft reached their performance limits. This meant their flying speed slightly exceeded $700 \mathrm{~km} / \mathrm{h}$. The flight altitude of an average fighter reached $12 \mathrm{~km}$, the special reconnaissance planes could even reach 14 to $15 \mathrm{~km}$. Good example for this process is one of the most well-known fighter plane of World War II, the Messerschmitt Bf 109, which went through numerous development phases. In Table 1 I have listed some of the main variants of this aircraft, illustrating that the more and more powerful engines did not yield a breakthrough result considering their flying speed.

Table 1. Performance data of Bf 109. [1]

\begin{tabular}{|l|c|l|c|c|}
\hline Version & Year & Engine & Power (HSP & ) \\
\hline Bf 109B & 1937 & Jumo 210 & 720 & 466 \\
\hline Bf 109D & 1938 & DB 600 & 960 & 514 \\
\hline Bf 109E & 1939 & DB 601A & 1175 & 569 \\
\hline Bf 109F & 1941 & DB 601N & 1200 & 614 \\
\hline Bf 109G & 1942 & DB 605 & 1475 & 643 \\
\hline Bf 109K & 1944 & DB 605D & 2000 (methanol injection) & 724 \\
\hline
\end{tabular}

Associate Professor, National University of Public Service, Institute of Military Aviation;

e-mail: varga.bela@uni-nke.hu

2 HSP-Horse Shaft Power 
These problems were already well-known even before World War II, although airplanes that time did not yet approached these limits. Using aerodynamic laws, it is easy to see that the necessary power is proportional with the cube of the flying speed, not to mention the ever-increasing amount of weaponry, which also required extra power. Accordingly, several researchers started to seek new directions for the aircraft engine developments. In the international arena, the British Frank Whittle's researches were particularly important, whose gas turbine engine in the 1930s (Figure 1, left) had all the components, which a modern gas turbine has.

Despite Whittle's leading role in gas turbine engine development, the first jet engine (Heinkel HE S3) built in an aircraft, was designed by Hans von Ohain. This engine pushed a Heinkel HE 178 aircraft, which accomplished its maiden flight on 27 August 1939.
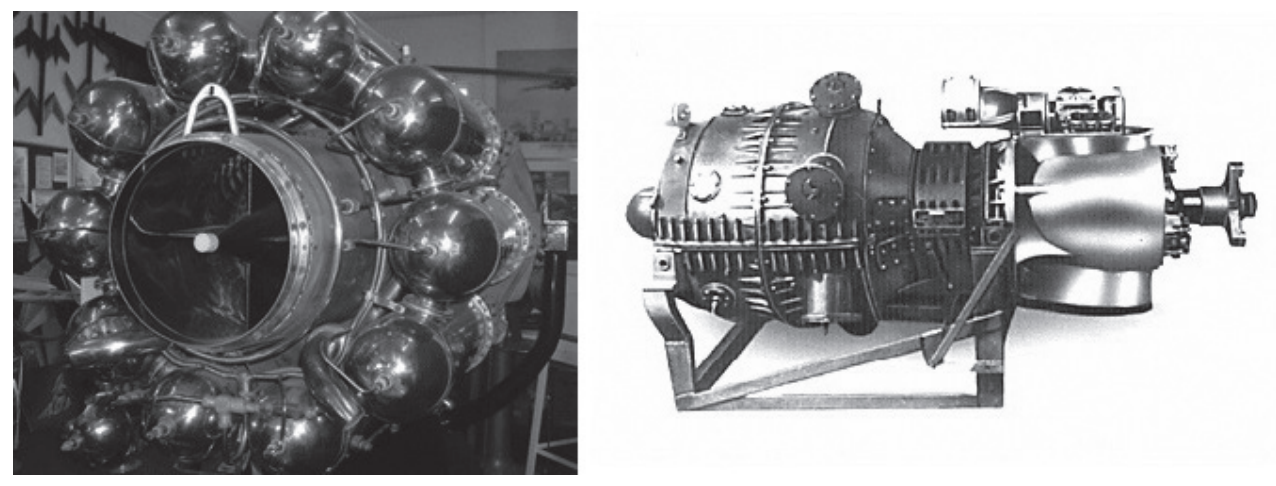

Figure 1. To the left Frank Whittle's engine, [2] to the right Jendrassik's shaft power producing gas turbine. [3]

But we should not forget about the Hungarian György Jendrassik, who was already a prestigious engineer at the Ganz factory when he started to develop his gas turbine engine. The first of his gas turbine patents was dated on $12^{\text {th }}$ March 1929. In 1938, his $75 \mathrm{~kW}$ power plant was the first in-use gas turbine in such a small size (Figure 1, right). His results worthily earned sensation. The machine achieved $21.2 \%$ effective thermal efficiency at $16,400 \mathrm{RPM}^{3}$ while it produced $72.5 \mathrm{~kW}$ shaft power. The maximum turbine inlet temperature was $475{ }^{\circ} \mathrm{C}$ and the compressor pressure ratio ${ }^{4}$ 2.2:1. With such a low turbine inlet temperature and small size, nobody achieved such a high efficiency, not even today. This good efficiency was achieved by a heat exchanger ${ }^{5}$ application. Both the axial compressor and the turbine had new unique solutions: both with slightly curved blades and stages having 50\% degree of reaction. ${ }^{6}$ Compressor efficiency was 85\%, turbine efficiency 88\%. [3] This gas turbine engine is also considered to be the ancestor of the shaft power producing gas turbines.

In the 40s, gas turbine engines (jet engines) appeared in such aeroplanes like the German Messerschmitt Me 262, Arado 234, or in the British Gloster Meteor (though the latter did not

\footnotetext{
RPMc-revolutions per minute.

4 Compressor pressure ratio: the ratio of the air pressure exiting the compressor to the air pressure entering the compressor.

5 Heat exchanger: compressor air is heated by the hot exhaust gas flow in a counter-flow heat exchanger.

$650 \%$ degree of reaction is when the pressure enthalpy change is equally shared by the stator and the rotor.
} 
have a battlefield role). In the 1950s, the gas turbine era was definitely and irreversibly blown into the aviation.

\section{Specialisation of Gas Turbine Engines}

In case of the first practically used gas turbine engines the thrust producing component was in the rear section of the engine, namely the nozzle. Consequently, it became the first category of gas turbine engines, the pure single-spool turbojet engine, shortly pure turbojet. However, their further specialization started almost immediately and three more distinct categories emerged. These are turboprops, turbofans and turboshafts.

In Figure 2, three, though somewhat modified, but practically pure turbojets (with afterburner $^{7}$ and two-spool with afterburner) are seen from the top right to the bottom right. The last two engines to the right are turbofan engines, their bypass ratio is the difference between them. ${ }^{8}$ The left-hand one is a low bypass ratio turbofan, which is nowadays the typical engine of multirole combat aircrafts and advanced training and light attack aircrafts.

The right-hand engine is a high bypass ratio turbofan which is used on passenger planes. However, the right-side engines also represent an evolutionary process; airliners went through this process from using pure turbojet (without afterburner) to high bypass ratio turbofan with 6-10 bypass ratio, significantly reducing their specific fuel consumption (increasing efficiency).

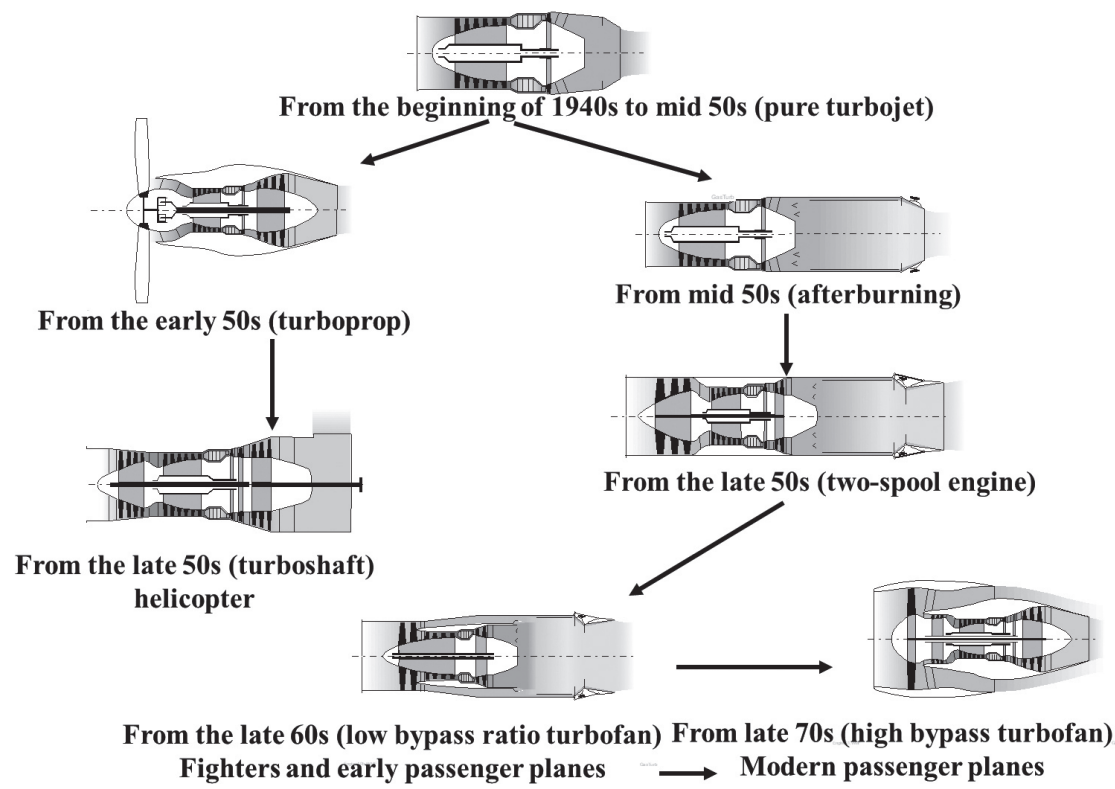

Figure 2. Evolution of gas turbine engines. [Edited by the author.]

\footnotetext{
7 Afterburner: thrust augmentation, achieved by injecting additional fuel into the jet pipe downstream of the turbine.

8 Bypass ratio: the ratio between the mass flow rate of the bypass stream to the mass flow rate entering the core.
} 
The left side turboprop engine is the engine of military transport aircrafts and short-range, typically small and medium-sized passenger planes. This is followed by a turboshaft, which is the typical engine of the helicopters.

Of course, the aircraft engines (maybe a more complex and appropriate expression would be propulsion systems) can be classified by how the thrust is generated, as shown in Figure 3. Thrust is the force which moves any aircraft forward, generated by the aircraft propulsion system. Different propulsion systems develop thrust in different ways, but all thrust is generated through the application of Newton's third law of motion, namely for every action there is an equal and opposite reaction. In any propulsion system some kind of working fluid is accelerated by the system and the reaction to this acceleration produces a force (thrust) on the system. Here we have to take into consideration that all aircraft propulsion systems can be divided into two basic components, such as a power generator and the accelerator. The power generator is actually, in most cases, a heat engine, which accomplishes wellknown classical thermodynamic cycles, like Otto, Diesel, Brayton. The accelerator is the structural unit which provides the thrust force, i.e. propeller, helicopter rotor, nozzle, fan stage or a combination of these items. A general derivation of the thrust equation shows that the amount of the generated thrust depends on the mass flow rate through the propulsion system and the difference between exit and inlet velocity (acceleration) of the working fluid.

It means that the principle of thrust derivation is the same in any case despite differences in structure of propulsion systems. But by the differences we can define some typical propulsion systems.

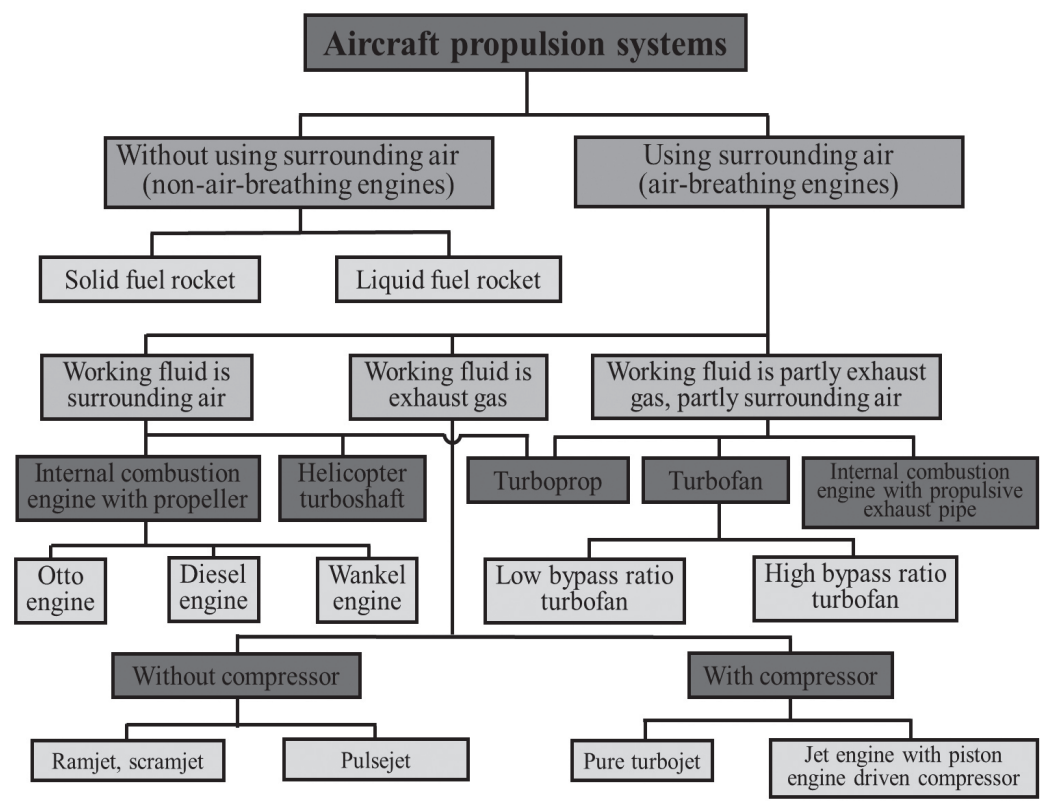

Figure 3. Classification of aircraft propulsion systems.

[Edited by the author.] 
From this point of view, aircraft (air-breathing) engines can be classified into three main categories, see the light brown row in Figure 3. Today the non-air-breathing engines can be excluded as aircraft propulsion systems:

- propulsion system where the accelerated working fluid is the surrounding air;

- propulsion system where the accelerated working fluid is the hot exhaust gas of the heat engine;

- propulsion system where the accelerated working fluid is partly the surrounding air partly the hot exhaust gas of the heat engine.

Apparently, gas turbine engines (turbojet, turbofan, turboprop, turboshaft) appear in all three of the aforementioned categories.

\section{The Born of Shaft Power Producing Gas Turbine}

Already in 1943, the possibility of using gas turbines to produce shaft power was considered in Germany to install them in newly-developed armoured vehicles, mainly in tanks. The design and construction of several more or less similar engines lasted from mid-1943 to early 1945. They were developed by Adolf Müller and signed from GT 101 to GT 103. With them a new category of gas turbines was born namely the turboshaft. The reason of this development was that the power to weight ratio of this gas turbines was much better than that of the piston engines with similar shaft power. Of course, there were disadvantages of the plan, too. The most significant is the expected bad thermal efficiency, which at that time was predetermined by the low compressor pressure ratio, at about 3:1, exacerbating by the low component efficiencies which further deteriorated the thermal efficiency. This, of course, caused high fuel consumption. This was somewhat counterbalanced by the fact that the lower quality kerosene used in gas turbines was more available than petrol at the end of the war, when Germany suffered from lack of fuel.

Another typical problem came from the fact that gas turbines typically work at high RPM. At low engine speeds, their torque is also low. Maintain a relatively narrow high-speed range and provide sufficient torque for the vehicle can be solved only with a complicated transmission and clutch system. The free-turbine (or with other words power-turbine) solution was already present in the first plans but when the load decreases, the overrun of the freeturbine is unmanageable.

Another idea was to drive a generator by the gas turbine shaft power to provide the required electric power for an electric motor. Later this was dropped and GT 101 (Figure 4, left) became a modified version of a BMW 003 aircraft gas turbine engine. The most important change is that the number of turbine stages were increased from one to three, and the extra stages added extra power to the gas generator shaft. ${ }^{9}$ However, the placement of the new power source in the vehicle caused serious problems, the delivered $857 \mathrm{~kW}$ shaft power at $450 \mathrm{~kg}$ mass was impressive enough comparing to the $462 \mathrm{~kW}$ and $1200 \mathrm{~kg}$ mass of the Maybach HL230 P30 piston engine. Another advantage was that the relatively heavy

9 Gas generator: the core of the gas turbine engine: compressor, combustor, (compressor) turbine. 
gas generator rotor (compressor and turbine) operated as a flywheel improving the off-road ability of the vehicle through terrain obstacles.
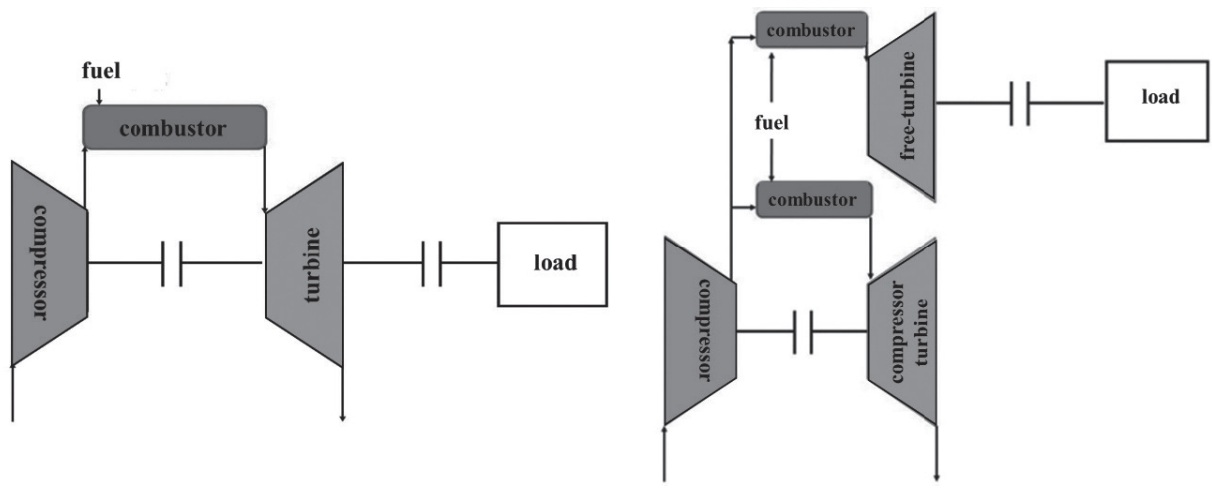

Figure 4. Left: the schematic of GT 101 gas turbine engine with undivided turbine (no freeturbine); right: GT 102 gas turbine engine with extra combustor and free-turbine. [Edited by the author.]

In case of GT 102 engine (Figure 4, right) a completely different concept was followed. The two-stage free-turbine was completely separated from the gas generator unit. Interestingly, it had its own combustor, which was air supplied by the compressor bleed air $^{10}$ of the gas generator unit (30\% of the total air supply). The over-run of the free-turbine in unloaded state was solved by releasing the working fluid to the surrounding atmosphere.

The GT 103 gas turbine engine was actually the version of the GT 102 with a heat exchanger. The idea was logical as the compressor of these engines had very low compressor pressure ratio and consequently low compressor exit temperature. The temperature of the exiting exhaust gas was much higher and could preheat the compressor air before entering into the combustor, significantly decreasing the fuel consumption. [4]

Although the above-mentioned engines were suitable to install into combat vehicles and preparations were made to do it, but the continuous deterioration of the military situation made it impossible to launch the serial production.

\section{The Adaptation of Shaft Power Producing Gas Turbines in Aviation}

In the late 40s and early 50s, turboshafts also appeared in aviation. The first low performance, so-called Auxiliary Power Units (APU) appeared on the board of aircrafts; their task was to start up the main engines of the aircraft, supply the on-board electrical energy system, and supply air to the air conditioning system.

10 Bleed air is compressed air that is taken from the compressor stage upstream of the combustor. 
In the second half of the 1950s, when helicopters achieved their adulthood, and it became an urgent problem to replace the relatively low-power and heavy piston engines, for which the turboshaft engines offered a good alternative. Only some types of light helicopters (e.g. Robinson) are exceptions, in which the piston engine has remained the power source. The first type of gas turbines used in helicopters was the Turbomeca Artouste turboshaft in 1950 (Figure 5), originally intended to use as an auxiliary power unit.

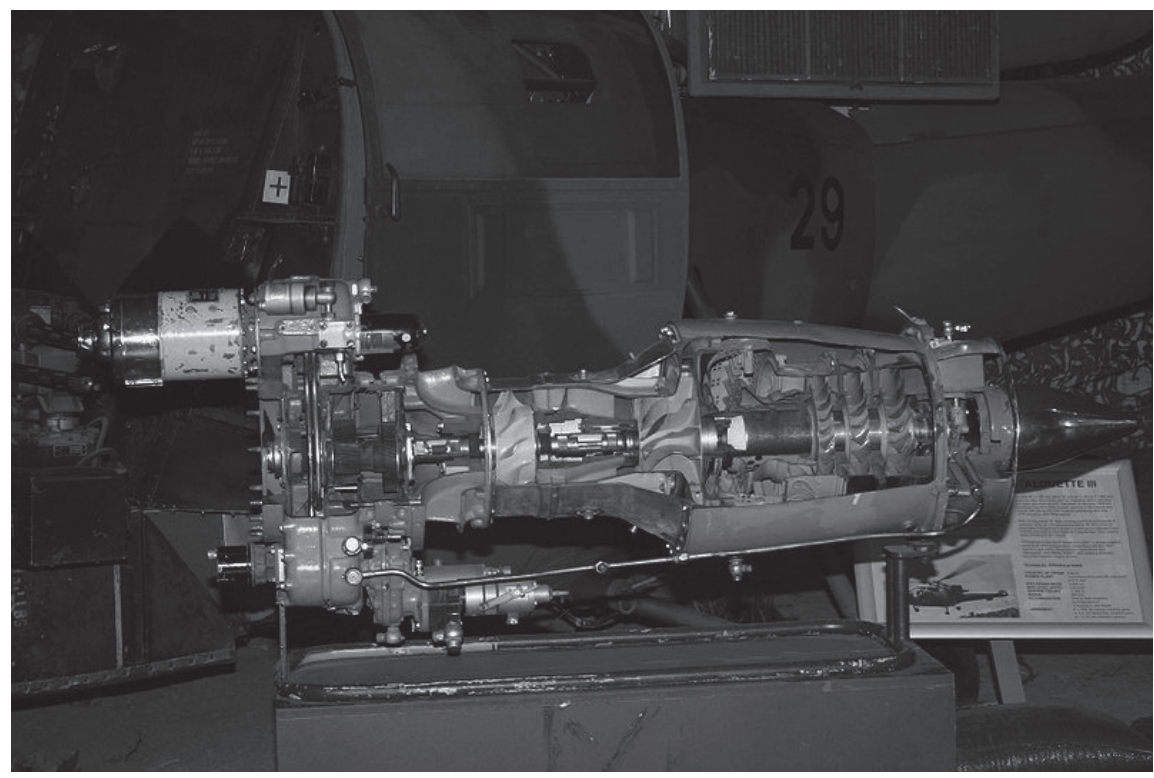

Figure 5. Turbomeca Artouste, the first turboshaft used in helicopters. [5]

This engine was capable of up to $210 \mathrm{~kW}$ shaft power and was incorporated into a number of helicopters such as Aérospatiale Alouette II, Aérospatiale Alouette III, Aerospatiale Lama, Aerothéque AC-14, Atlas XH-1 Alpha, IAR 317 and aircrafts like Handley Page Victor, Hawker Siddeley Trident, Vickers VC10 as auxiliary power units. [5]

Of course, the great powers did not wait idly and the developments started. In the United States, Lycoming with Anselm Franz, the creator of the Jumo 004 gas turbine engine in Nazi Germany, began to build a 373-522 kW turboprop engine family on behalf of the US Air Force. The T53 and T55 turboshaft engines came from this project. The T53 were built into helicopters or aircrafts such as Bell UH-1 Iroquois and AH-1 Huey Cobra and Grumman OV-1 Mohawk airplane. [7]

It should be noted that there is a considerable structural similarity between turboprop and turboshaft engines. A number of manufacturers produces turboprop and turboshaft variants of a particular type of gas turbine engine. However, there are two fundamental differences between these two categories. One is that in case of turboprops in general (except small turboprop aircrafts) a small portion of the energy of the exhaust gas is converted into thrust in the nozzle, thereby providing $10-15 \%$ of the total thrust by the nozzle instead of using additional turbine stage(s) or by modifying the turbine to allow the remaining part of energy to be converted into shaft power. The other difference is that in turboprops the propeller and 
the transmission are structurally part of the engine. In case of helicopter turboshafts, the main gearbox is structurally connected to the airframe and the thrust force is transferred directly to the airframe, not to the engine.

In the early 1950s, General Electric also received a \$ 3 million contract from the Government of the United States to develop a new light-weight, reliable gas turbine engine suitable to use as a helicopter power source. The secret program was launched under the name of XT-58 and the final result was a $596 \mathrm{~kW}$ shaft power turboshaft engine (Figure 6); its mass was only $181 \mathrm{~kg}$.

This engine was further developed by 1957 and its output shaft power improved to 783 $\mathrm{kW}$ and its mass decreased to $114 \mathrm{~kg}$. This year the piston engine of the Sikorsky HSS-1F helicopter was replaced by two T58 turboshaft engines and became the first US gas turbine powered helicopter. Recognizing the practical importance of the new development, a number of US helicopter manufacturers (Sikorsky, Kaman) built the newly developed T58 engine in their helicopters. [9]

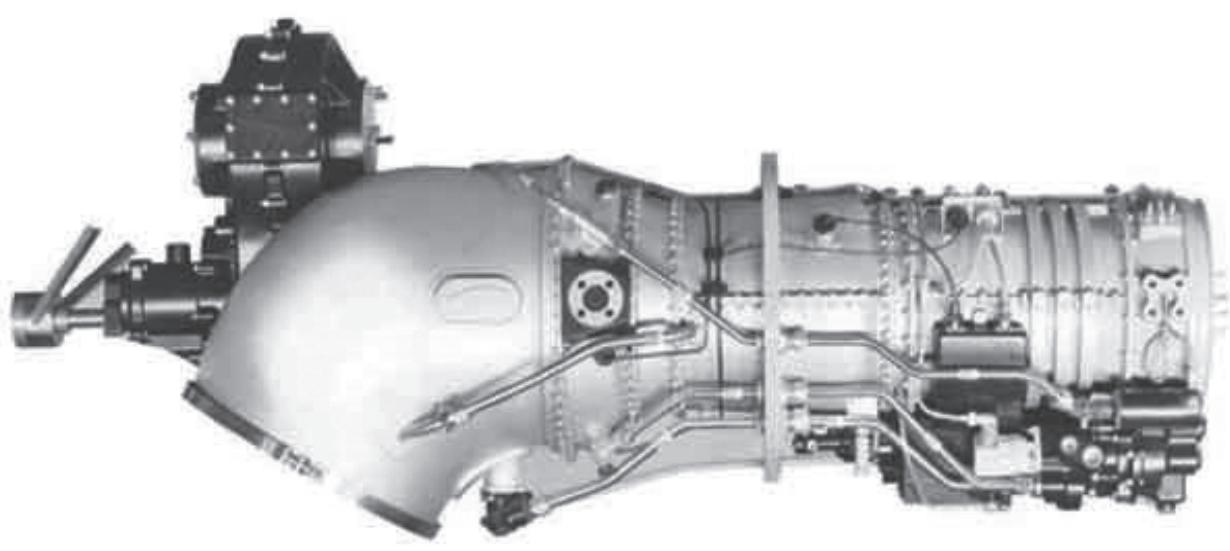

Figure 6. The XT-58 turboshaft engine is mostly identical with the arrangement used today. [9]

The first Soviet second-generation helicopters appeared in 1957. This Mi-6 was a heavy transport and a troop carrier helicopter. In the second half of the 50s Mikhail Leontyevich Mil, the head of the Mil design bureau decided to design a revolutionary new helicopter for the replacement of the that time already obsolete $\mathrm{Mi}-4$ helicopters in the medium-size transport helicopter category.

On 20 February 1958, the Council of Ministers of the Soviet Union adopted this proposal and ordered the development of a helicopter capable of carrying 1.5 to 2 tonnes of payload with a V-8 type designation, which would be equipped with an Ivchenko AI-24V turboprop engine modified for use on a single rotor helicopter. The single-engine V-8 helicopter first flew on 24 June 1961. Recognizing the disadvantages of the AI-24V engine, the Izotov Engine Design Bureau was instructed to develop a truly helicopter application optimized gas turbine engine. The TV-2VM and D-25V engines used for Mi-6 were originally designed for fixed wing aircraft. The new TV2-117A turboshaft (Figure 7) and the VR-8 main gearbox 
designed by the Izotov Bureau was delivered in the summer of 1962. The new engine produced $1118 \mathrm{~kW}$ shaft power at take-off rate of power with relatively good specific parameters. [10]

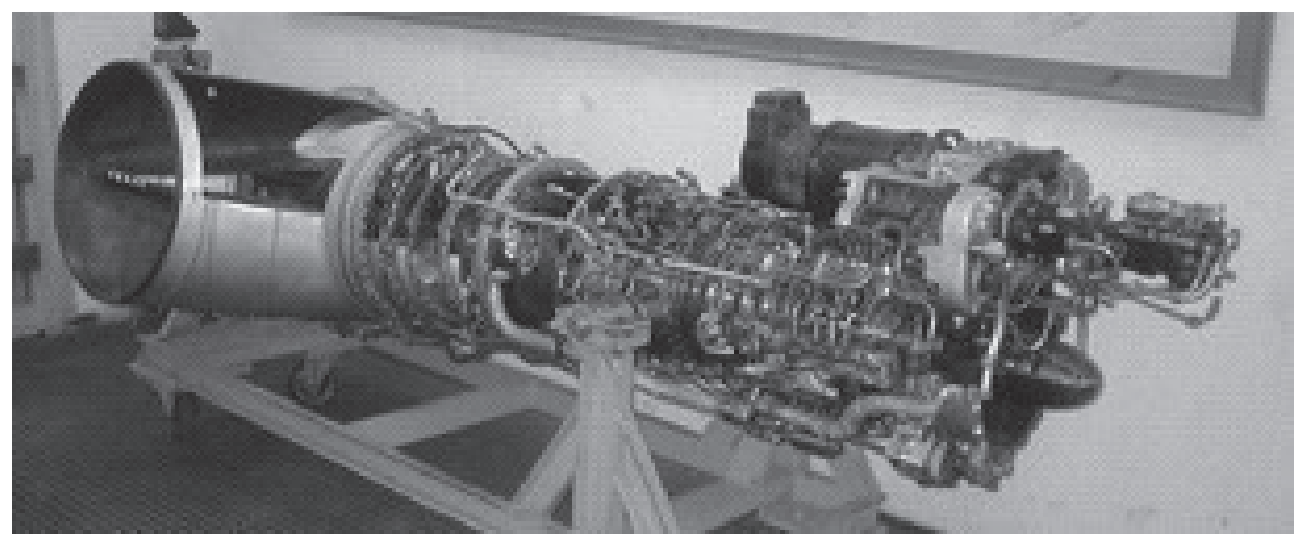

Figure 7. TV2-117A, the first Soviet turboshaft engine designed for helicopter application. [Author's own photo.]

The TV3-117 turboshaft family became the power source of the next-generation Soviet helicopters. Its structural layout is similar to that of the TV2-117A engine, apart from the two additional compressor stages, which provide higher compressor pressure ratio (9.4:1 compared to 6.6:1), and the mass flow rate ${ }^{11}(8.7 \mathrm{~kg} / \mathrm{s}$ compared to $6.8 \mathrm{~kg} / \mathrm{s})$ providing higher shaft power (1640 kW compared to $1108 \mathrm{~kW}$ ). These engines were used in almost all Russian medium-size transport and attack helicopters: Mi-SMT, Mi-17, Mi-14, Mi-24, Mi-25, Mi-35, Mi-28, Ka-27, Ka-28, Ka-29, Ka-31, Ka-32, Ka-50 and Ka-52, demonstrating their reliability. [6]

Of course, the urgent claim for these new engines was soon to be targeted by most engine manufacturers and today 10-12 of them dominate this segment of the market. The number of their types and their modifications is almost uncountable. They can be found in Reference [7] (and Annex 1) where we can track the most important manufacturers, their products and the most important parameters of their engines.

In this period the classical principle of this gas turbine category (Figure 8), which was mostly embodied in the free-turbine application, became quite common. The so-called gas generator rotor (compressor and compressor turbine) is not mechanically connected to the free-turbine, which allows independent free-turbine speed from the gas generator unit speed. Accordingly, the free-turbine has only gas dynamical connection with the gas generator unit, i.e. the residual energy of the hot gas is utilized in the free turbine, ensuring the required shaft power.

11 Mass flow rate: amount of air flows through the engine per second $(\mathrm{kg} / \mathrm{s})$. 


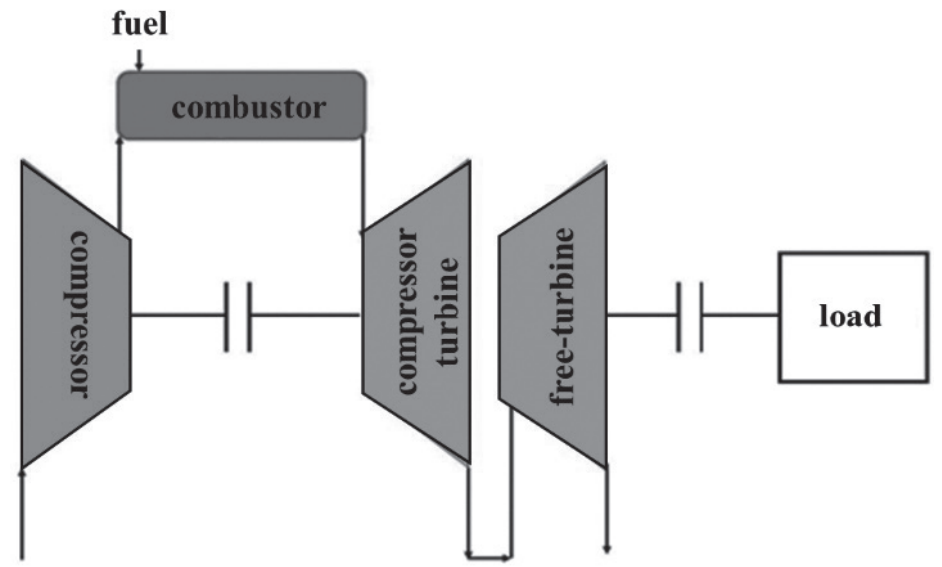

Figure 8. The schematic of turboshafts used today. [Edited by the author.]

Though the principle has not changed since the 1950s, helicopter turboshafts have undergone through significant development. The layout has changed as the reverse-flow combustor became more common (Figure 9/a; d), some of the turbine stages were incorporated into the ring-like inner combustor case (Figure 9/a; d). In many cases, a front drive is used (Figure 9/a; c), so that the first reduction gear stage would remain part of the engine itself (Figure 9/a; b). As a result, the engines became more compact and lighter. Their specific parameters and thermal efficiency has improved despite the fact that the aforementioned structural changes often had a negative effect on their component efficiencies and through it on their thermal efficiency. In Figure 9/a; b; c the gas generator (blue) and the free-turbine (brown) is clearly divided, which is shown by their different colour.

The RTM 322 engine schematics, shown in Figure 9/d, illustrates one of the most typical structural solutions. The compressor's 3-5 axial stages are followed by a centrifugal compressor stage mounted on the same shaft. The reason for using a centrifugal stage is that it can replace $4-5$ axial stages.
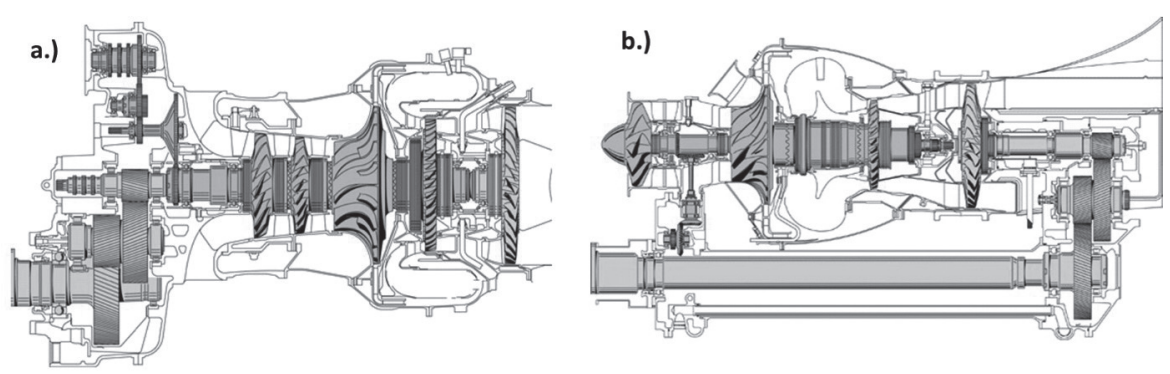

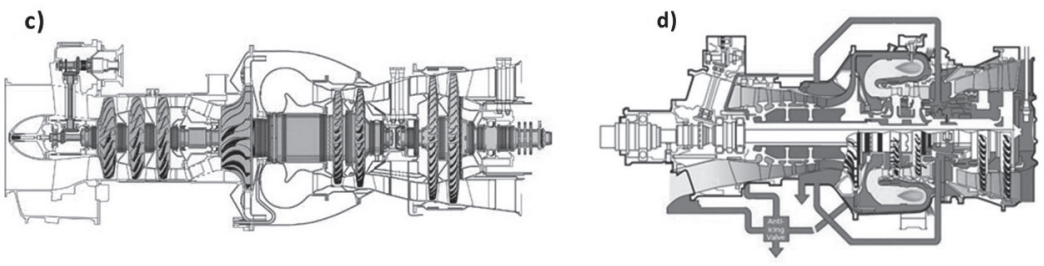

Figure 9. Schematics of different turboshaft arrangements. [11]

This solution reduces the length of the engine. On the other hand, though the centrifugal compressor usually has a lower polytrophic efficiency than the axial compressor, but due to the low air mass flow rate, the short blade length of the last axial compressor stage would produce an even worse polytrophic efficiency than the centrifugal compressor. The reverse flow combustor also reduces the length of the engine, although it slightly increases the combustor pressure loss. The turbine blades are cooled in the first stages, though the turbine inlet temperature is lower than in other gas turbine categories. Free-turbine blades are generally not, or only minimally cooled. The exhaust pipe system serves only to allow the exhaust gas into the surrounding atmosphere.

Figure 10 also depicts a modern helicopter turboshaft engine, which is the product of the MTR consortium and doubly built in, powers the Eurocopter Tiger helicopter.
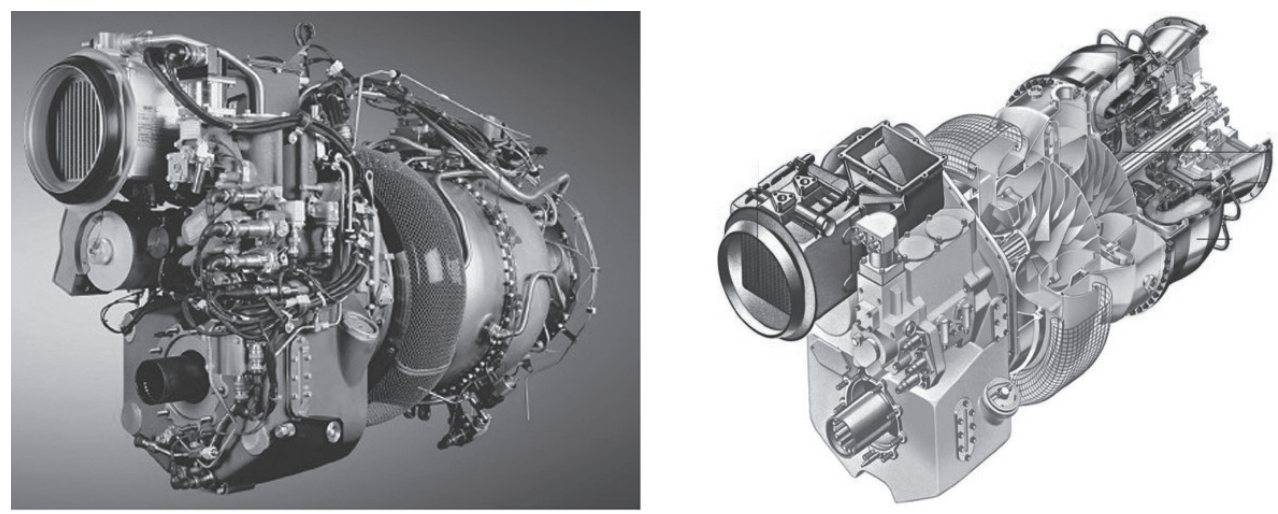

Figure 10. MTR 390, the power source of Eurocopter Tiger. [12]

Compared to the previous layouts, its novelty is that even the first axial stages are replaced with a centrifugal stage. This provides an even shorter and compact layout, reduces the tendency of compressor stall, ${ }^{12}$ and achieves a satisfactory compressor and turbine efficiency at low air mass flow rate. Table 2 illustrates the performance, mass and size data of the two variants.

12 Compressor stall: the flow separation in the compressor due to the deformed velocity triangles. 
Table 2. Most important data of two MTR 390 engine variants. [12]

\begin{tabular}{|l|c|c|}
\hline $\begin{array}{l}\text { MTR 390 engine variants } \\
\text { Uninstalled, ISA }{ }^{13} \mathbf{H}=\mathbf{0} \text { m }\end{array}$ & MTR 390-2C & MTR 390-E \\
\hline Measure of the rate of power (kW) & 958 & 1094 \\
\hline Emergency power (30s) (kW) & 1160 & 1322 \\
\hline Maximum continuous power (kW) & 873 & 1000 \\
\hline Specific fuel consumption (take off) $(\mathrm{kg} / \mathrm{kWh}]$ & 0.284 & $<0.299$ \\
\hline Specific fuel consumption (max. cont.) $(\mathrm{kg} / \mathrm{kWh})$ & 0.280 & $<0.293$ \\
\hline Air mass flow rate (take off) $(\mathrm{kg} / \mathrm{s})$ & 3.2 & 3.6 \\
\hline Compressor pressure ratio (take off) & 13 & 14 \\
\hline Free turbine RPM (1/min) & 8320 & 8320 \\
\hline Length (mm) & 1078 & 1078 \\
\hline Width (mm) & 442 & 442 \\
\hline Height (mm) & 682 & 682 \\
\hline Mass (kg) & 169 & $<179$ \\
\hline
\end{tabular}

\section{Statistical Analysis of Helicopter Turboshaft Engines}

When we examine the development of the category, of course we have to consider many factors. These include specific fuel consumption (ratio of fuel consumption to shaft power), specific net work output (ratio of shaft power to air mass flow rate), specific power (ratio of shaft power to engine mass), reliability, operability, which of course affect the tacticaltechnical operation of helicopters.

Diagrams from Figure 11 to 14 display the different engine performance features as a function of shaft power processing the Annex 1 with Excel function manager. What is apparent at first sight in Figure 11 is that in terms of engine shaft power, the helicopter engines can be divided into three distinct categories by their shaft power, with some well-perceived gaps among them. The smallest performance category provides up to $200-800 \mathrm{~kW}$ take off power. The medium performance category includes power plants ranging from 1000 to 2200 $\mathrm{kW}$, while in the large category there are 2500-3700 kW shaft power outputs. Obviously, this latter category of my analysis contains the fewest pieces. This does not mean that there are only that many engines in this category but due to the relatively small number of heavy transport helicopter types and the relatively low production number, the choice is not so numerous like in small and medium categories.

Of course, in some cases, we can find some data out of the aforementioned interval. The T64-GE-100's $3228 \mathrm{~kW}$ performance and $13.3 \mathrm{~kg} / \mathrm{s}$ air mass flow rate is high, but it is also dwarfed by the Mi-26 helicopter's D-136 engine with $8501 \mathrm{~kW}$ output. Due to its relatively high air consumption, its specific fuel consumption is also quite good (0.266 kg/ $\mathrm{kWh})$.

13 ISA-International Standard Atmosphere. 


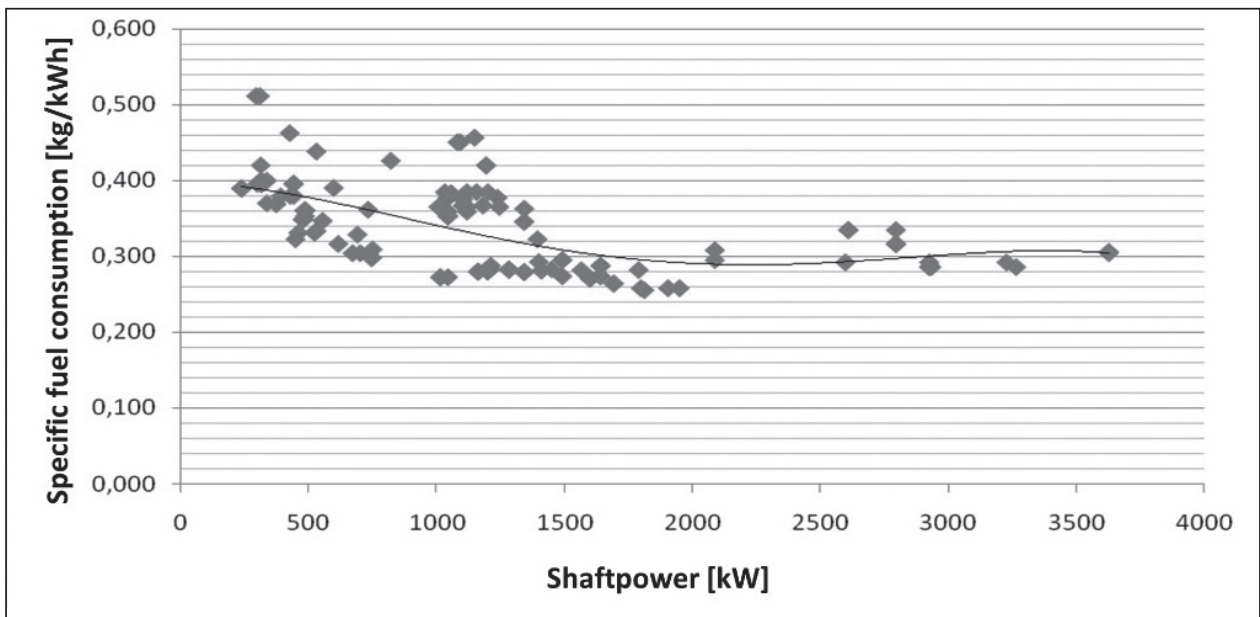

Figure 11. Specific fuel consumption vs. shaft power diagram. [Edited by the author.]

However, in the low shaft power category we can also meet specific fuel consumption values around $0.5 \mathrm{~kg} / \mathrm{kWh}$. For example, the Mi-2 helicopter's GTD 350, which is wellknown in our practice, has a $0.489 \mathrm{~kg} / \mathrm{kWh}$ specific fuel consumption which is extremely high. This can be explained by the age and relatively small size of the engine. In most cases the available data for the analysis is the specific fuel consumption, but this can easily be converted into thermal efficiency using Equation 1 and 2.

$\eta_{t h}=\frac{P[W]}{\dot{Q}_{i n}\left[\frac{J}{s}\right]}=\frac{P[W]}{\dot{m}_{\text {fuel }}\left[\frac{\mathrm{kg}}{\mathrm{s}}\right] \cdot F H V\left[\frac{\mathrm{J}}{\mathrm{kg}}\right]} \operatorname{míg}$ a $\quad S F C=\frac{3600 \cdot \dot{m}_{\text {fuel }}\left[\frac{\mathrm{kg}}{\mathrm{s}}\right]}{P[\mathrm{~kW}]}\left[\frac{\mathrm{kg}}{\mathrm{kWh}}\right] 1$

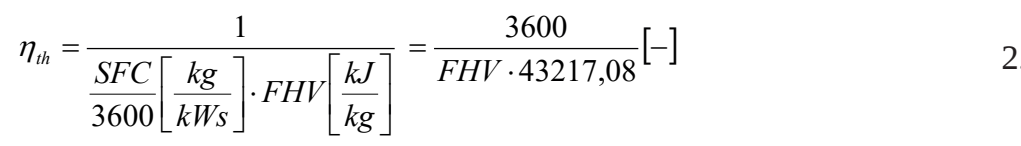

Where:

- $\quad \eta_{\mathrm{th}}$ : thermal efficiency [-];

- $\quad$ P: shaft power $(\mathrm{kW})$;

- $\dot{Q}_{\text {in }}$ input heat flow (J/s);

- $\quad \dot{m}_{\text {fuel }}$ fuel mass flow rate $(\mathrm{kg} / \mathrm{s})$;

- $\quad$ FHV: fuel heating value (J/kg);

- $\quad$ SFC: specific fuel consumption (kg/kWh). 
Of course, Equation 2 gives the correct result if the specific fuel consumption is replaced by $\mathrm{kg} / \mathrm{kWh}$ according to the derivation. For the conversion, the fuel heating value is still requested. Here, the standard 18,580 BTU/lb was adopted from the Boeing's Jet Fuel Characteristics workbook, which corresponds to 43,217,080 J/kg after the unit conversion. [8]

If we examine the diagram in Figure 11, it is interesting to note the nature of the average specific fuel consumption vs. shaft power curve. Considerable change can be seen at higher shaft power. The average specific fuel consumption decreases from about $0.4 \mathrm{~kg} / \mathrm{kWh}$ to 0.3 $\mathrm{kg} / \mathrm{kWh}$. Converting them to thermal efficiency, the related efficiencies are $21 \%(0.4 \mathrm{~kg} /$ $\mathrm{kWh})$ and $28 \%(0.3 \mathrm{~kg} / \mathrm{kWh})$ giving a considerable difference.

This, of course, is only indirectly related to shaft power. The real reason is that generally higher shaft power needs larger geometric dimensions, which results in better component efficiencies (compressor, combustor, turbine efficiencies, for example due to the relative smaller blade tip clearances). This is even more true if the maximum air consumption is at least $30 \mathrm{~kg} / \mathrm{s}$ or so like in turbofans. Nowadays their thermal efficiency is well above $40 \%$ at maximum rate of power. At the same time in case of helicopter engines, thermal efficiency around $30 \%$ is reasonable. We can conclude, that the thermal efficiency of helicopter turboshafts is generally between $17 \%$ and $32 \%$. Worse thermal efficiency (higher specific fuel consumption) is expected at smaller and (or) older engines. Of course, differences in technological levels among individual manufacturers may also appear in efficiency, but the technological gap is less and less present in today's globalizing world. According to the company data, RTM 322-04/08, RTM 322-01/9 and RTM 322-01/9A nowadays represent the best specific fuel consumption $(0.258 \mathrm{~kg} / \mathrm{kWh})$, which results in slightly more than $30 \%$ thermal efficiency.

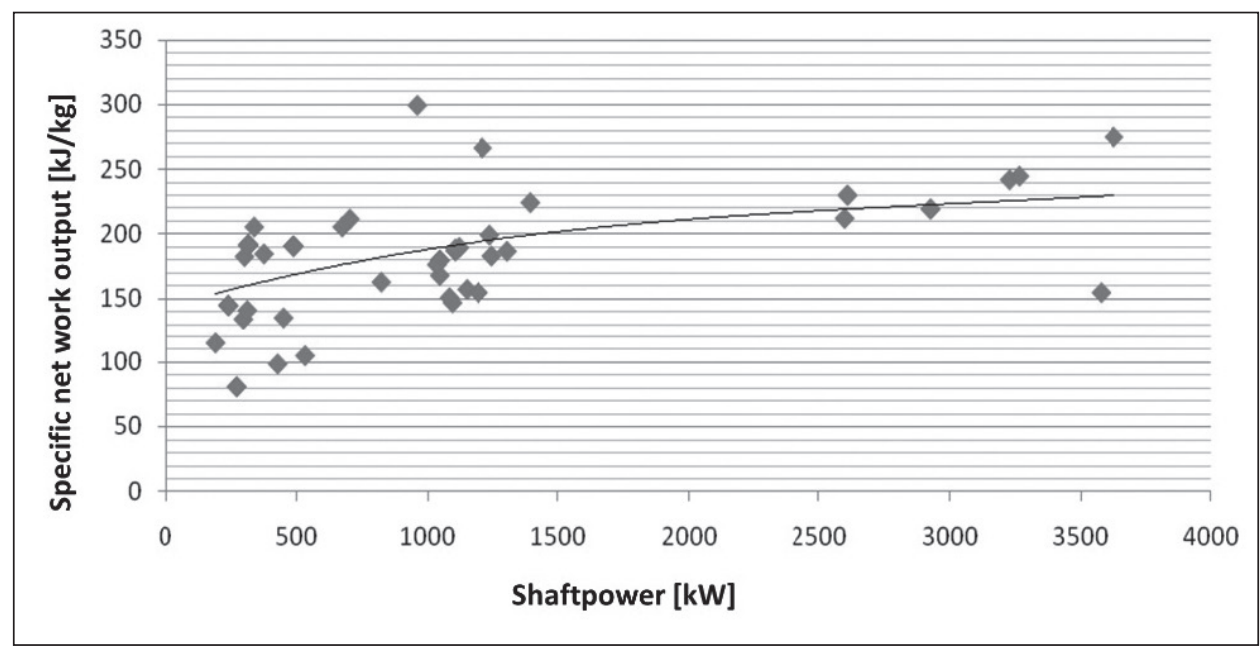

Figure 12. Specific net work output vs. shaft power diagram. [Edited by the author.]

The next important quality indicator of turboshafts is the specific net work output (Figure 12). This indicator has a close relationship with the geometric dimensions and mass of the engine. The specific net work output of the engine is higher if smaller mass flow rate is required to generate the same shaft power, reducing the size and consequently 
the mass of the engine. The situation is the same as it was concerning thermal efficiency. Engines with higher shaft power (larger engines) produce better specific net work output. Considering the trend line, the difference is almost $100 \mathrm{~kJ} / \mathrm{kg}$, but there are engines from $100 \mathrm{~kJ} / \mathrm{kg}$ to $300 \mathrm{~kJ} / \mathrm{kg}$ specific net work output.

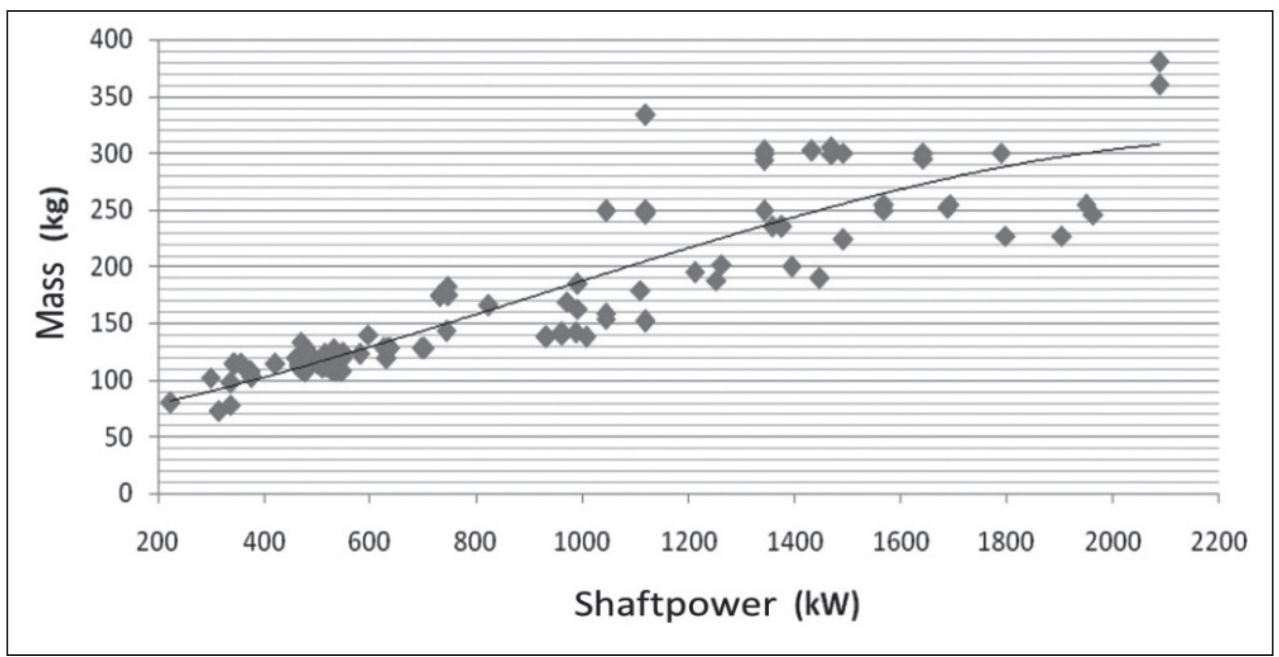

Figure 13. Specific power vs. shaft power diagram. [Edited by the author.]

In Figure 13 the engine mass versus shaft power is displayed which generally ranges from at about $80 \mathrm{~kg}$ to $300 \mathrm{~kg}$. This information is not surprising because it is clear that higher shaft power needs larger and heavier engine. The next diagram in Figure 14 is more informative. This diagram represents the shaft power to mass ratio (specific power) of turboshaft engines, which also enables the comparison of one design to another. Like in previous cases the larger size provides better values. The average specific power ranges from $3 \mathrm{~kW} / \mathrm{kg}$ to $7 \mathrm{~kW} / \mathrm{kg}$, but there are engines with $8 \mathrm{~kW} / \mathrm{kg}$ specific power, which is quite excellent. 


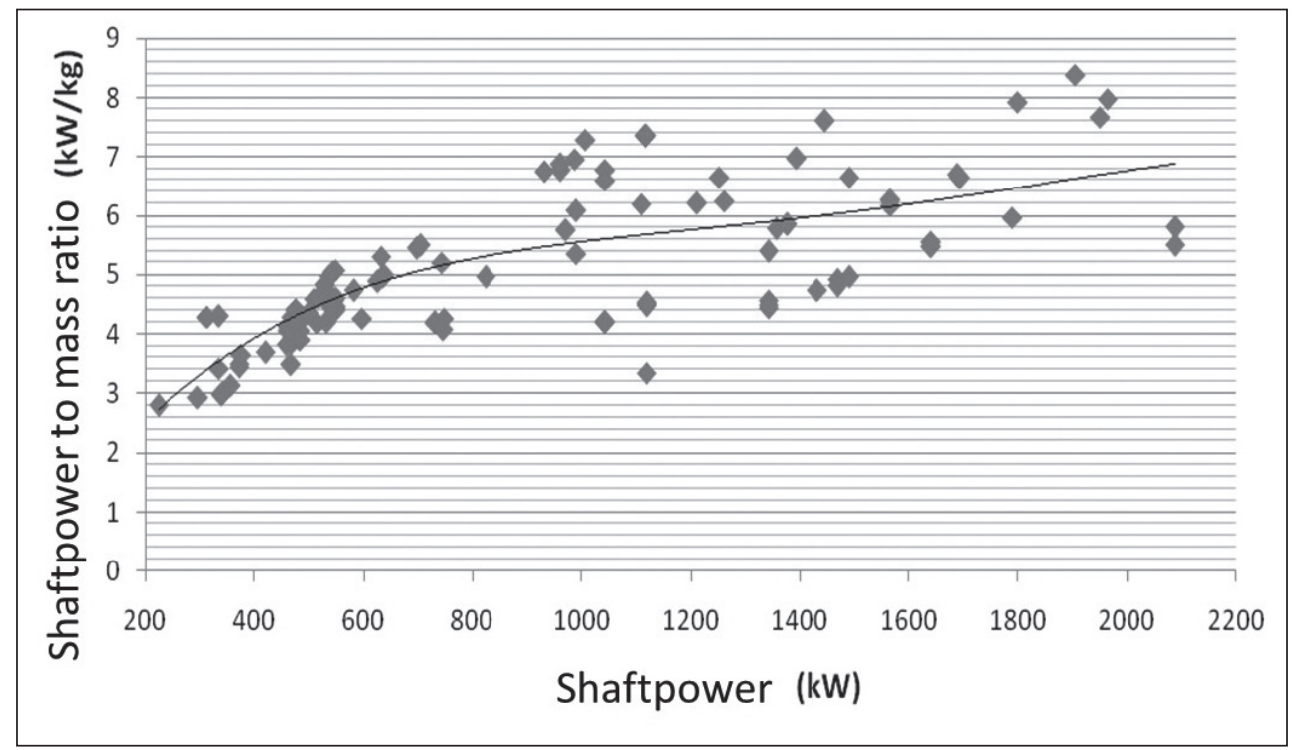

Figure 14. Specific power vs. shaft power diagram. [Edited by the author.]

The most important results of this computer aided processing of engine data are that it clearly displays the size dependence of these engine parameters. Even the largest engines in this category are small comparing them, for example, to turbofans. This fact predetermines the relatively week values of their specific parameters, like specific fuel consumption, specific net work output and specific power, which are in fact important quality indicators. Inside the category, this trend significantly appears in Figure 11, 12 and 14. In accordance with this, it is misconducting to compare turboshaft engines by these indicators to other gas turbine engine categories, what is more even inside the category if their shaft power is not quite close to each other.

We can ask the question: does size really matter? The answer for the question is obvious. The size is extremely important considering these indicators. We can firmly state that the helicopter turboshaft category is penalised by its own small size and inside the category this size dependence is even more clear.

Summarizing the essence of this statistics, usually we can find the following turboshaft engine data:

$\begin{array}{ll}\text { shaft power: } & 200-3700 \mathrm{~kW} \\ \text { compressor pressure ratio: } & 7: 1-16: 1 \\ \text { mass flow rate: } & 2-15 \mathrm{~kg} / \mathrm{s} \\ \text { turbine inlet temperature: } & 1100-1500 \mathrm{~K} \\ \text { specific fuel consumption: } & 0.25-0.5 \mathrm{~kg} / \mathrm{kWh} \\ \text { thermal efficiency: } & 17-32 \% \\ \text { engine mass: } & 80-400 \mathrm{~kg} \\ \text { specific power: } & 3-8 \mathrm{~kW} / \mathrm{kg}\end{array}$




\section{Conclusions}

The leading military powers began to use helicopters in the early fifties. The experiences of local wars (Korea, Algeria, Vietnam, Middle East, etc.) offered newer and newer areas of their application and contributed to their specialization and the rapid growth of their number. Within a few years, due to the increasing take-off mass and payload, helicopters outgrew the available piston engines and the only alternative was a lightweight, highperformance power source that the turboshaft engines are perfectly suited for.

Of course, over the past 60 years, many improvements and innovations have changed dramatically the turboshaft category. The increased compressor pressure ratio, turbine inlet temperature, the FADEC ${ }^{14}$ system highly improved their performance, while the long-term reliability and maintainability has also increased. Nonetheless, some indicators of helicopter turboshaft engines, like thermal efficiency and all specific parameters are significantly worse than the average of other gas turbine engine categories. Unfortunately, there is not much to do with this fact, because it is coded in their relatively small size and their structural arrangement.

\section{References}

[1] The Messerschmitt Bf 109. www.chuckhawks.com/me-109.htm (Downloaded: 02.02.2018)

[2] Whittle Jet Engine W2-700. http://it.wikipedia.org/wiki/File:Whittle_Jet_Engine_W2-700. JPG (Downloaded: 02.02.2018)

[3] Jendrassik György. www.sztnh.gov.hu/feltalalok/jendrass.html (Downloaded: 02.02.2018)

[4] GT 101. http://en.wikipedia.org/wiki/GT_101 (Downloaded: 15.01.2018)

[5] Turbomeca Artouste. http://en.wikipedia.org/wiki/Turbomeca_Artouste (Downloaded: 02.02.2018)

[6] Tuboshaft Engine TV3-117. www.vkms.ru/production_en.shtml (Downloaded: 02.03.2013)

[7] Engine Manufacturers. Helicopter Annual, (2009), 57-63. https://slidex.tips/download/ rolls-royce-turbomeca-ltd-andy-upton-marketing-manager-rtm322-4-grosvenor-place (Downloaded: 14.02.2018)

[8] LAWICKI, D.: Jet Fuel Characteristics, Boeing, 2002. www.docstoc.com/docs/7654823/ JET-FUEL-FACTS (Downloaded: 02.03.2013)

[9] GE Aviation. www.geaviation.com/engines/military/t58/ (Downloaded: 02.03.2013)

[10] Klimov. http://en.klimov.ru/production/helicopter/TV2-117/ (Downloaded: 15.03.2013)

[11] Rolls-Royce. www.rolls-royce.com/Images/RTM 322_tcm92-6703.pdf (Downloaded: 10.02.2013)

[12] MTU Aero Engines. www.mtu.de/engines/military-aircraft-engines/helicopters/mtr390/ (Downloaded: 02.02.2018)

14 FADEC—Full Authority Digital Engine Control 
Annex 1/1. Most important manufacturers, types, technical data. [7] (N/A: no data)

\begin{tabular}{|c|c|c|c|c|c|c|c|}
\hline Manufacturer & $\begin{array}{c}\text { Type of the } \\
\text { engine }\end{array}$ & $\begin{array}{l}\text { Helicopter, in } \\
\text { which the en- } \\
\text { gine is built in }\end{array}$ & 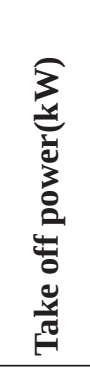 & 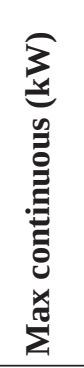 & 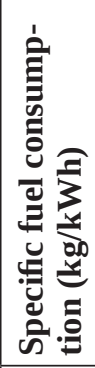 & 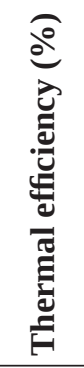 & 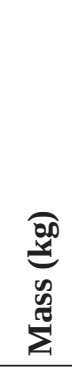 \\
\hline $\begin{array}{l}\text { General } \\
\text { Electric }\end{array}$ & T58-GE-1 & $\begin{array}{l}\mathrm{CH}-3 \mathrm{~B} / \mathrm{C}, \\
\mathrm{SH}-3 \mathrm{~A}, \mathrm{~S}-61 \mathrm{~A}\end{array}$ & 962 & N/A & N/A & N/A & 142 \\
\hline $\begin{array}{l}\text { General } \\
\text { Electric }\end{array}$ & T58-GE-2 & AB204AS & 988 & N/A & N/A & N/A & 142 \\
\hline $\begin{array}{l}\text { General } \\
\text { Electric }\end{array}$ & T58-GE-3 & $\mathrm{TH}-1 \mathrm{~F}, \mathrm{UH}-1 \mathrm{~F} / \mathrm{P}$ & 962 & N/A & N/A & N/A & 140 \\
\hline $\begin{array}{l}\text { General } \\
\text { Electric }\end{array}$ & T58-GE-5 & $\begin{array}{l}\mathrm{CH}-3 \mathrm{E}, \mathrm{HH}- \\
\text { 3E/F, SH-3E/F }\end{array}$ & 1118 & N/A & 0.365 & 22.8 & 152 \\
\hline $\begin{array}{l}\text { General } \\
\text { Electric }\end{array}$ & T58-GE-6 & $\mathrm{CH}-46 \mathrm{~A}$ & 932 & N/A & N/A & N/A & 138 \\
\hline $\begin{array}{l}\text { General } \\
\text { Electric }\end{array}$ & T58-GE-8B & $\begin{array}{l}\mathrm{SH}-2 \mathrm{~F}, \mathrm{SH}-3 \mathrm{G}, \\
\mathrm{UH}-2 \mathrm{~A} / \mathrm{B} / \mathrm{C}, \\
\mathrm{CH}-113 \mathrm{~A}\end{array}$ & 932 & N/A & N/A & N/A & 138 \\
\hline $\begin{array}{l}\text { General } \\
\text { Electric }\end{array}$ & T58-GE-8F & $\begin{array}{l}\mathrm{SH}-2 \mathrm{~F}, \mathrm{SH}-3 \mathrm{G}, \\
\mathrm{UH}-2 \mathrm{C}, \\
\mathrm{CH}-124 \mathrm{~A} / \mathrm{B}\end{array}$ & 1007 & N/A & 0.365 & 22.8 & 138 \\
\hline $\begin{array}{l}\text { General } \\
\text { Electric }\end{array}$ & T58-GE-10 & $\begin{array}{l}\mathrm{CH}-46 \mathrm{D} / \mathrm{F}, \\
\mathrm{UH}-46 \mathrm{D} / \mathrm{F}, \\
\mathrm{HH}-2 \mathrm{D}, \mathrm{HH}-3 \mathrm{~F}, \\
\mathrm{SH}-3 \mathrm{D} / \mathrm{G} / \mathrm{H}, \\
\mathrm{ASH}-3 \mathrm{~A} / \mathrm{D} / \mathrm{TS}, \\
\mathrm{AS}-61 \mathrm{R}\end{array}$ & 1044 & N/A & 0.377 & 22.1 & 158 \\
\hline $\begin{array}{l}\text { General } \\
\text { Electric }\end{array}$ & T58-GE-16 & $\mathrm{CH}-46 \mathrm{E}$ & 1394 & N/A & 0.322 & 25.9 & 200 \\
\hline $\begin{array}{l}\text { General } \\
\text { Electric }\end{array}$ & T58-GE-100 & $\begin{array}{l}\text { ASH-3H, } \\
\text { CH-124A/B Sea } \\
\text { King }\end{array}$ & 1118 & N/A & N/A & N/A & 152 \\
\hline $\begin{array}{l}\text { General } \\
\text { Electric }\end{array}$ & T58-GE-402 & $\begin{array}{l}\text { CH-46D/E, } \\
\text { SH-3H, UH-3H }\end{array}$ & 1118 & N/A & N/A & N/A & 152 \\
\hline $\begin{array}{l}\text { General } \\
\text { Electric }\end{array}$ & T64-GE-1 & $\mathrm{CH}-53 \mathrm{~A}$ & 2297 & N/A & N/A & N/A & N/A \\
\hline $\begin{array}{l}\text { General } \\
\text { Electric }\end{array}$ & T64-GE-3 & $\mathrm{HH}-53 \mathrm{~B}$ & 2297 & N/A & N/A & N/A & N/A \\
\hline $\begin{array}{l}\text { General } \\
\text { Electric }\end{array}$ & T64-GE-6 & $\begin{array}{l}\text { CH-53A, } \\
\text { TH-53A }\end{array}$ & 2125 & N/A & N/A & N/A & N/A \\
\hline $\begin{array}{l}\text { General } \\
\text { Electric }\end{array}$ & T64-GE-7 & $\begin{array}{l}\mathrm{CH}-53 \mathrm{C}, \\
\mathrm{HH}-53 \mathrm{~B} / \mathrm{C} / \mathrm{H}\end{array}$ & 2926 & N/A & N/A & N/A & N/A \\
\hline
\end{tabular}




\begin{tabular}{|c|c|c|c|c|c|c|c|}
\hline Manufacturer & $\begin{array}{l}\text { Type of the } \\
\text { engine }\end{array}$ & $\begin{array}{l}\text { Helicopter, in } \\
\text { which the en- } \\
\text { gine is built in }\end{array}$ & 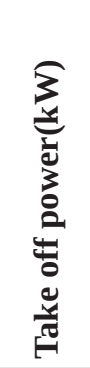 & 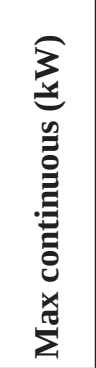 & 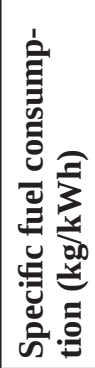 & 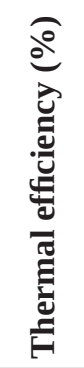 & 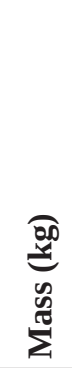 \\
\hline $\begin{array}{l}\text { Honeywell } \\
\text { Defense and } \\
\text { Space }\end{array}$ & HTS900 & Bell ARH (1) & 744 & 664 & 0.320 & 26.0 & 143 \\
\hline $\begin{array}{l}\text { Honeywell } \\
\text { Engines \& } \\
\text { Systems }\end{array}$ & AL5512 & $\begin{array}{l}\text { BV234 \& } \\
\text { BV-234LR (2) }\end{array}$ & 3039 & 2218 & 0.330 & 25.2 & 354 \\
\hline $\begin{array}{l}\text { Honeywell } \\
\text { Engines \& } \\
\text { Systems }\end{array}$ & LTS101-600A-3A & $\begin{array}{l}\text { Eurocopter } \\
\text { AS350B (1) Eu- } \\
\text { rocopter AS350D } \\
\text { (1) Eurocopter } \\
\text { AS350A (1) }\end{array}$ & 485 & 466 & 0.347 & 24.0 & 120 \\
\hline $\begin{array}{l}\text { Honeywell } \\
\text { Engines \& } \\
\text { Systems }\end{array}$ & LTS101-650B-1 & $\begin{array}{l}\text { Eurocopter } \\
\text { BK-117A (2) }\end{array}$ & 470 & 418 & 0.347 & 24.0 & 122 \\
\hline $\begin{array}{l}\text { Honeywell } \\
\text { Engines \& } \\
\text { Systems }\end{array}$ & LTS101-750C-1 & $\begin{array}{l}\text { Bell 222B, UT } \\
\text { (2) }\end{array}$ & 510 & 487 & 0.353 & 23.6 & 111 \\
\hline $\begin{array}{l}\text { Honeywell } \\
\text { Engines \& } \\
\text { Systems }\end{array}$ & LTS101-750B-2 & $\begin{array}{l}\text { Eurocopter/U.S. } \\
\text { Coast Guard } \\
\text { HH-65A (2) }\end{array}$ & 515 & 491 & 0.347 & 24.0 & 123 \\
\hline $\begin{array}{l}\text { Honeywell } \\
\text { Engines \& } \\
\text { Systems }\end{array}$ & LTS101-750B-1 & $\begin{array}{l}\text { Eurocopter } \\
\text { BK-117B (2) }\end{array}$ & 468 & 440 & 0.353 & 23.6 & 134 \\
\hline $\begin{array}{l}\text { Honeywell } \\
\text { Engines \& } \\
\text { Systems } \\
\end{array}$ & LTS101-850B-2 & $\begin{array}{l}\text { Eurocopter } \\
\text { HH-65A (2) }\end{array}$ & 582 & 556 & 0.347 & 24.0 & 123 \\
\hline $\begin{array}{l}\text { Honeywell } \\
\text { Engines \& } \\
\text { Systems }\end{array}$ & LTS101-700D-2 & $\begin{array}{l}\text { Eurocopter } \\
\text { AS350B2 }\end{array}$ & 546 & 485 & 0.347 & 24.0 & 120 \\
\hline $\begin{array}{l}\text { Honeywell } \\
\text { Engines \& } \\
\text { Systems }\end{array}$ & LTS101-650C-3 & Bell 222 (2) & 470 & 446 & 0.347 & 24.0 & 110 \\
\hline $\begin{array}{l}\text { Honeywell } \\
\text { Engines \& } \\
\text { Systems }\end{array}$ & $\begin{array}{l}\text { LTS101- } \\
600 \mathrm{~A}-2 /-3\end{array}$ & $\begin{array}{l}\text { Eurocopter } \\
\text { AS350D (1) }\end{array}$ & 459 & 440 & 0.347 & 24.0 & 120 \\
\hline $\begin{array}{l}\text { Honeywell } \\
\text { Engines \& } \\
\text { Systems }\end{array}$ & T55-L-712 & $\mathrm{CH}-47 \mathrm{D}(2)$ & 2796 & 2237 & 0.322 & 25.9 & 354 \\
\hline
\end{tabular}




\begin{tabular}{|c|c|c|c|c|c|c|c|}
\hline Manufacturer & $\begin{array}{l}\text { Type of the } \\
\text { engine }\end{array}$ & $\begin{array}{l}\text { Helicopter, in } \\
\text { which the en- } \\
\text { gine is built in }\end{array}$ & 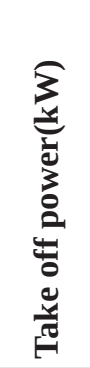 & 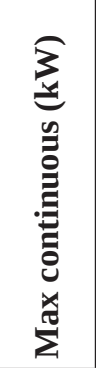 & 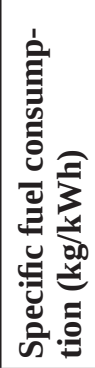 & 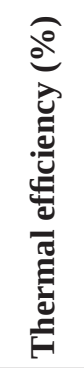 & 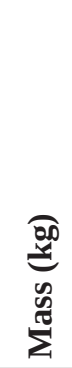 \\
\hline $\begin{array}{l}\text { Honeywell } \\
\text { Engines \& } \\
\text { Systems }\end{array}$ & T55-L-712F & HCMK2/2A (2) & 3218 & 2349 & 0.319 & 26.1 & 354 \\
\hline $\begin{array}{l}\text { Honeywell } \\
\text { Engines \& } \\
\text { Systems }\end{array}$ & T55-L-712 S/SB & CH-47D (2) & 3262 & 2349 & 0.315 & 26.4 & 354 \\
\hline $\begin{array}{l}\text { Honeywell } \\
\text { Engines \& } \\
\text { Systems }\end{array}$ & T55-L-712E & $\mathrm{CH}-47$ (2) & 2796 & 2237 & 0.322 & 25.9 & 354 \\
\hline $\begin{array}{l}\text { Honeywell } \\
\text { Engines \& } \\
\text { Systems }\end{array}$ & T55-L-712 S/SC & $\mathrm{CH}-47 \mathrm{D}(2)$ & 2796 & 2237 & 0.322 & 25.9 & 354 \\
\hline $\begin{array}{l}\text { Honeywell } \\
\text { Engines \& } \\
\text { Systems }\end{array}$ & T55-L-714A & $\begin{array}{l}\text { CH-47S/D \& } \\
\text { HCMK3 (2) }\end{array}$ & 3629 & 3108 & 0.316 & 26.4 & 399 \\
\hline $\begin{array}{l}\text { Honeywell } \\
\text { Engines \& } \\
\text { Systems }\end{array}$ & T55-L-714 & MH-47E (2) & 3562 & 3069 & 0.312 & 26.7 & 399 \\
\hline $\begin{array}{l}\text { Honeywell } \\
\text { Engines \& } \\
\text { Systems }\end{array}$ & T55-GA-714A & $\mathrm{CH}-47 \mathrm{D} / \mathrm{F}(2)$ & 3562 & 3069 & 0.312 & 26.7 & 399 \\
\hline $\begin{array}{l}\text { Honeywell } \\
\text { Engines \& } \\
\text { Systems }\end{array}$ & T5313B & $\begin{array}{l}\text { Bell 205A1, Bell } \\
\text { 205B }\end{array}$ & 1044 & 932 & 0.365 & 22.8 & 249 \\
\hline
\end{tabular}


Annex 1/2. Most important manufacturers, types, technical data. [7]

\begin{tabular}{|c|c|c|c|c|c|c|c|}
\hline Manufacturer & Type of the engine & $\begin{array}{l}\text { Helicopter, in } \\
\text { which the en- } \\
\text { gine is built in }\end{array}$ & 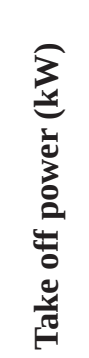 & 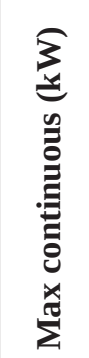 & 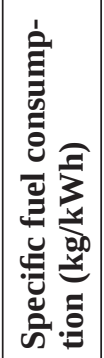 & 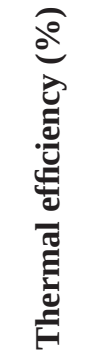 & 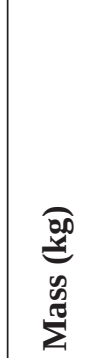 \\
\hline $\begin{array}{l}\text { Honeywell } \\
\text { Engines \& } \\
\text { Systems }\end{array}$ & T5317B & $\begin{array}{l}\text { Bell 205A1, Fuji } \\
\text { Bell 205B }\end{array}$ & 1119 & 1007 & 0.367 & 22.6 & 250 \\
\hline $\begin{array}{l}\text { Honeywell } \\
\text { Engines \& } \\
\text { Systems }\end{array}$ & T5317BCV & $\begin{array}{l}\text { B210, Huey II, } \\
\text { Bell } 205\end{array}$ & 1342 & 1119 & 0.346 & 24.0 & 249 \\
\hline $\begin{array}{l}\text { Honeywell } \\
\text { Engines \& } \\
\text { Systems }\end{array}$ & T53-L-13B & $\begin{array}{l}\text { Bell UH-1, } \\
\text { Agusta AB205 }\end{array}$ & 1044 & 932 & 0.365 & 22.8 & 249 \\
\hline $\begin{array}{l}\text { Honeywell } \\
\text { Engines \& } \\
\text { Systems }\end{array}$ & T53-L-703 & $\begin{array}{l}\text { Bell AH-1, Bell } \\
\text { UH II }\end{array}$ & 1119 & 1007 & 0.395 & 21.0 & 247 \\
\hline LHTEC & CTS800-4N & $\begin{array}{l}\text { AgustaWestland } \\
\text { Super lynx (2) } \\
\text { AgustaWestland/ } \\
\text { Turkey T129 (2) }\end{array}$ & 991 & 920 & 0.28 & 29.7 & 185 \\
\hline LHTEC & CTS800-4K & $\begin{array}{l}\text { Shimaywa US2 } \\
\text { (1) }\end{array}$ & 991 & 920 & 0.28 & 29.7 & 163 \\
\hline MTR & MTR 390-2C & $\begin{array}{l}\text { Eurocopter Tiger } \\
(2)\end{array}$ & 972 & 885 & 0.276 & 30.1 & 169 \\
\hline MTRI & MTR 390-E & $\begin{array}{l}\text { Eurocopter Tiger } \\
\text { (2) }\end{array}$ & 1110 & 1009 & 0.288 & 28.9 & 179 \\
\hline $\begin{array}{l}\text { Pratt \& Whit- } \\
\text { ney Canada }\end{array}$ & PT6B-36A & $\begin{array}{l}\text { Sikorsky S-76B } \\
(2)\end{array}$ & 732 & 661 & 0.353 & 23.5 & 174 \\
\hline $\begin{array}{l}\text { Pratt \& Whit- } \\
\text { ney Canada }\end{array}$ & PT6B-36B & $\begin{array}{l}\begin{array}{l}\text { Sikorsky S-76B } \\
(2)\end{array} \\
\end{array}$ & 732 & 661 & 0.353 & 23.5 & 175 \\
\hline $\begin{array}{l}\text { Pratt \& Whit- } \\
\text { ney Canada }\end{array}$ & PT6B-37A & $\begin{array}{l}\text { Agusta A119 } \\
\text { Koala (1) } \\
\end{array}$ & 747 & 650 & 0.361 & 23.0 & 175 \\
\hline $\begin{array}{l}\text { Pratt \& Whit- } \\
\text { ney Canada }\end{array}$ & PT6C-67A & $\begin{array}{l}\text { Bell Agusta } \\
\text { BA609 (2) }\end{array}$ & 1447 & 1249 & N/A & N/A & 190 \\
\hline $\begin{array}{l}\text { Pratt \& Whit- } \\
\text { ney Canada }\end{array}$ & PT6C-67C & $\begin{array}{l}\text { Agusta AW139 } \\
\text { (2) }\end{array}$ & 1252 & 1142 & 0.308 & 27.0 & 188 \\
\hline $\begin{array}{l}\text { Pratt \& Whit- } \\
\text { ney Canada }\end{array}$ & PT6C-67D & $\begin{array}{l}\text { (UH-1H) Dy- } \\
\text { nCorp Global } \\
\text { Eagle (1) }\end{array}$ & 1262 & 1182 & 0.308 & 27.0 & 202 \\
\hline
\end{tabular}




\begin{tabular}{|c|c|c|c|c|c|c|c|}
\hline Manufacturer & Type of the engine & $\begin{array}{l}\text { Helicopter, in } \\
\text { which the en- } \\
\text { gine is built in }\end{array}$ & 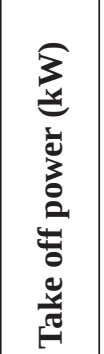 & 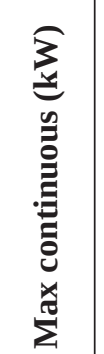 & 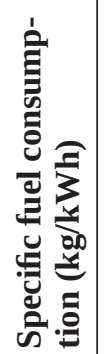 & 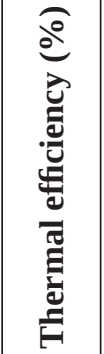 & 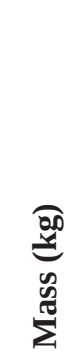 \\
\hline $\begin{array}{l}\text { Pratt \& Whit- } \\
\text { ney Canada }\end{array}$ & PT6C-67E & EC175 & 1324 & $\mathrm{~N} / \mathrm{A}$ & N/A & N/A & N/A \\
\hline $\begin{array}{l}\text { Pratt \& Whit- } \\
\text { ney Canada }\end{array}$ & PT6T-3 TwinPac ${ }^{\circledR}$ & $\begin{array}{l}\text { Bell UH-1N, } \\
\text { Bell CUH-1N, } \\
\text { Bell VH-1N, } \\
\text { Bell AH-1J, Bell } \\
\text { AH-1T, Bell/ } \\
\text { Agusta-Bell 212, } \\
\text { Sikorsky S-58T } \\
\end{array}$ & 1342 & 1193 & 0.362 & 23.0 & 294 \\
\hline $\begin{array}{l}\text { Pratt \& Whit- } \\
\text { ney Canada }\end{array}$ & $\begin{array}{l}\text { PT6T-3B/BF } \\
\text { TwinPac }{ }^{\circledR}\end{array}$ & $\begin{array}{l}\text { Bell/Agusta-Bell } \\
\text { 212 Bell/Agus- } \\
\text { ta-Bell 412 Bell/ } \\
\text { Agusta-Bell } \\
\text { 412SP (1) }\end{array}$ & 1342 & 1193 & 0.365 & 0.228 & 299 \\
\hline $\begin{array}{l}\text { Pratt \& Whit- } \\
\text { ney Canada }\end{array}$ & $\begin{array}{l}\text { PT6T-3BE/BG } \\
\text { TwinPac }{ }^{\circledR}\end{array}$ & $\begin{array}{l}\text { Bell } 412 \text { HP, } \\
\text { Agusta-Bell } 412 \\
\text { Agusta-Bell } 412 \\
\text { HP (1) }\end{array}$ & 1342 & 1193 & 0.365 & 22.8 & 302 \\
\hline $\begin{array}{l}\text { Pratt \& Whit- } \\
\text { ney Canada }\end{array}$ & $\begin{array}{l}\text { PT6T-3D/DE/ DF } \\
\text { TwinPac } ®\end{array}$ & $\begin{array}{l}\text { Bell/Agusta-Bell } \\
412 \text { EP (1) }\end{array}$ & 1432 & 1268 & 0.365 & 22.8 & 302 \\
\hline $\begin{array}{l}\text { Pratt \& Whit- } \\
\text { ney Canada }\end{array}$ & $\begin{array}{l}\text { PT6T-6 } \\
\text { TwinPac }{ }^{\circledR}\end{array}$ & \begin{tabular}{|l|} 
Agusta-Bell \\
212/412 Sikorsky \\
S-58T (1)
\end{tabular} & 1469 & 1301 & 0.36 & 23.1 & 299 \\
\hline $\begin{array}{l}\text { Pratt \& Whit- } \\
\text { ney Canada }\end{array}$ & $\begin{array}{l}\text { PT6T-6B } \\
\text { TwinPac }{ }^{\circledR}\end{array}$ & $\begin{array}{l}\text { Agusta-Bell } 412 \\
\text { HP (1)* }\end{array}$ & 1469 & 1301 & 0.36 & 23.1 & 305 \\
\hline $\begin{array}{l}\text { Pratt \& Whit- } \\
\text { ney Canada }\end{array}$ & PW206A & MD Explorer & 477 & 423 & N/A & N/A & 108 \\
\hline $\begin{array}{l}\text { Pratt \& Whit- } \\
\text { ney Canada }\end{array}$ & PW206B & EC135P1 & 463 & 419 & N/A & N/A & 112 \\
\hline $\begin{array}{l}\text { Pratt \& Whit- } \\
\text { ney Canada }\end{array}$ & PW206B2 & EC135P2 & 518 & 457 & N/A & N/A & 112 \\
\hline $\begin{array}{l}\text { Pratt \& Whit- } \\
\text { ney Canada }\end{array}$ & PW206C & $\begin{array}{l}\text { Agusta } \\
\text { A109Power (2) } \\
\end{array}$ & 477 & 423 & N/A & N/A & 108 \\
\hline $\begin{array}{l}\text { Pratt \& Whit- } \\
\text { ney Canada }\end{array}$ & PW206E & MD Explorer & 477 & 423 & N/A & N/A & 108 \\
\hline $\begin{array}{l}\text { Pratt \& Whit- } \\
\text { ney Canada }\end{array}$ & PW207C & $\begin{array}{l}\text { Agusta A109 } \\
\text { Grand (2) }\end{array}$ & 548 & 466 & N/A & N/A & 108 \\
\hline
\end{tabular}


Annex 1/3. Most important manufacturers, types, technical data. [7]

\begin{tabular}{|c|c|c|c|c|c|c|c|}
\hline Manufacturer & $\begin{array}{c}\text { Type of the } \\
\text { engine }\end{array}$ & $\begin{array}{l}\text { Helicopter, in } \\
\text { which the en- } \\
\text { gine is built in }\end{array}$ & 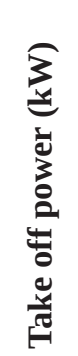 & 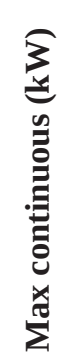 & 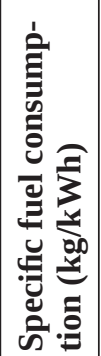 & 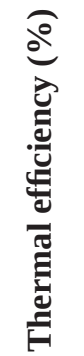 & 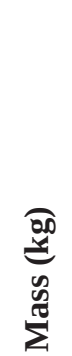 \\
\hline $\begin{array}{l}\text { Pratt \& Whit- } \\
\text { ney Canada }\end{array}$ & PW207D & Bell M427 (2) & 529 & 466 & N/A & N/A & 110 \\
\hline $\begin{array}{l}\text { Pratt \& Whit- } \\
\text { ney Canada }\end{array}$ & PW207D1 & Bell 429 (2) & 536 & 474 & N/A & N/A & 108 \\
\hline $\begin{array}{l}\text { Pratt \& Whit- } \\
\text { ney Canada }\end{array}$ & PW207E & MD Explorer (2) & 529 & 466 & N/A & N/A & 109 \\
\hline $\begin{array}{l}\text { Pratt \& Whit- } \\
\text { ney Canada }\end{array}$ & PW207K & Kazan Ansat (2) & 544 & 466 & N/A & N/A & 108 \\
\hline $\begin{array}{l}\text { Pratt \& Whit- } \\
\text { ney Canada }\end{array}$ & PW210S & $\begin{array}{l}\text { Sikorsky S-76D } \\
(2)\end{array}$ & 802 & 802 & N/A & N/A & N/A \\
\hline Rolls-Royce & RR 300 & $\begin{array}{l}\text { Robinson R66 } \\
(1)\end{array}$ & 224 & 179 & 0.408 & 20.4 & 80 \\
\hline Rolls-Royce & RR 500TP & $\begin{array}{l}\text { Under } \\
\text { development }\end{array}$ & 298 & 283 & 0.335 & 24.9 & 102 \\
\hline Rolls-Royce & Model 250-C20B & $\begin{array}{l}\text { Agusta A109A } \\
\text { (2).Bell 206B } \\
\text { JetRanger (1). } \\
\text { Bell 206L } \\
\text { LongRanger } \\
\text { (1).Eurocopter } \\
\text { BO105 (2). } \\
\text { Hiller FH1100 } \\
\text { (1) MD } \\
\text { Helicopters } \\
\text { MD500D (1) } \\
\end{array}$ & 313 & 313 & 0.395 & 21.1 & 73 \\
\hline Rolls-Royce & Model 250-C20F & $\begin{array}{l}\text { Eurocopter } \\
\text { AS355F (2) }\end{array}$ & 313 & 313 & 0.395 & 21.1 & 73 \\
\hline Rolls-Royce & Model 250-C20J & \begin{tabular}{|l|} 
Bell 206B \\
JetRanger III (1) \\
Bell TH-57 (1) \\
Bell TH-67 (1) \\
\end{tabular} & 313 & 313 & 0.395 & 21.1 & 73 \\
\hline
\end{tabular}




\begin{tabular}{|c|c|c|c|c|c|c|c|}
\hline Manufacturer & $\begin{array}{l}\text { Type of the } \\
\text { engine }\end{array}$ & $\begin{array}{l}\text { Helicopter, in } \\
\text { which the en- } \\
\text { gine is built in }\end{array}$ & 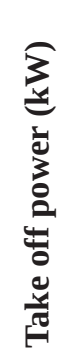 & 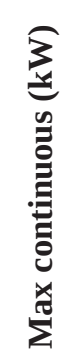 & 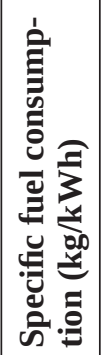 & 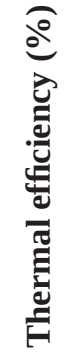 & 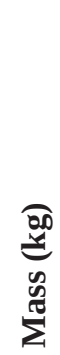 \\
\hline Rolls-Royce & Model 250-C20R & $\begin{array}{l}\text { Agusta A109C } \\
\text { (2)Bell 206B } \\
\text { JetRanger III } \\
\text { (1) HeliLynx } \\
\text { 355FX (2) Star- } \\
\text { flex 355F2 (2) } \\
\text { Kamov Ka-226 } \\
\text { (2) MD Helicop- } \\
\text { ters MD500E (1) } \\
\text { MD Helicopters } \\
\text { MD520N (1) } \\
\text { PZL SW-4 (1) } \\
\text { Tridair Gemini } \\
\text { ST (2) } \\
\end{array}$ & 336 & 336 & 0.370 & 22.5 & 78 \\
\hline Rolls-Royce & Model 250-C20W & $\begin{array}{l}\text { Enstrom 480B } \\
\text { (1) Northrop } \\
\text { Grumman } \\
\text { Fire-Scout } \\
\text { (1) Schweizer } \\
\text { 330SP/333 (1) }\end{array}$ & 313 & 313 & 0.395 & 21.1 & 73 \\
\hline Rolls-Royce & Model 250-C28 & $\begin{array}{l}\text { Eurocopter BO } \\
\text { 105LS (2) }\end{array}$ & 373 & 373 & 0.359 & 23.2 & 107 \\
\hline Rolls-Royce & Model 250-C28B & $\begin{array}{l}\text { Bell 206L-1 } \\
\text { LongRanger II } \\
\text { (1) }\end{array}$ & 373 & 373 & 0.359 & 23.2 & 108 \\
\hline Rolls-Royce & Model 250-C30 & $\begin{array}{l}\text { MD Helicopters } \\
\text { MD530F (1) }\end{array}$ & 485 & 415 & 0.360 & 23.1 & 114 \\
\hline Rolls-Royce & Model 250-C30G & Bell $230(2)$ & 485 & 415 & 0.360 & 23.1 & 115 \\
\hline Rolls-Royce & Model 250-C30M & $\begin{array}{l}\text { Soloy AS350 } \\
\text { AllStar(1) }\end{array}$ & 485 & 415 & 0.360 & 23.1 & 114 \\
\hline Rolls-Royce & Model 250-С30P & $\begin{array}{l}\text { Bell 206L-3 } \\
\text { LongRanger III } \\
\text { (1)Bell 206L-4 } \\
\text { LongRanger IV } \\
\text { (1) }\end{array}$ & 485 & 415 & 0.360 & 23.1 & 114 \\
\hline
\end{tabular}




\begin{tabular}{|c|c|c|c|c|c|c|c|}
\hline Manufacturer & $\begin{array}{c}\text { Type of the } \\
\text { engine }\end{array}$ & $\begin{array}{l}\text { Helicopter, in } \\
\text { which the en- } \\
\text { gine is built in }\end{array}$ & 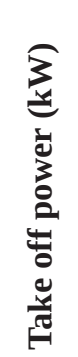 & 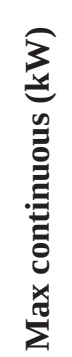 & 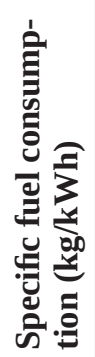 & 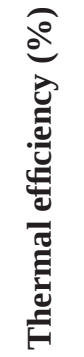 & 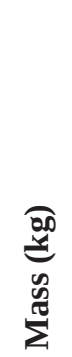 \\
\hline Rolls-Royce & $\begin{array}{l}\text { Model 250- } \\
\text { C30R/3 }\end{array}$ & $\begin{array}{l}\text { Bell OH-58D } \\
\text { (1) Boeing Little } \\
\text { Bird ULB (1) } \\
\text { MD Helicopters } \\
\text { AH/MH-6 (1) }\end{array}$ & 485 & 415 & 0.360 & 23.1 & 124 \\
\hline Rolls-Royce & Model 250-C30S & $\begin{array}{l}\text { Sikorsky S-76A } \\
(2)\end{array}$ & 485 & 415 & 0.360 & 23.1 & 114 \\
\hline Rolls-Royce & Model 250-C40 & Bell $430(2)$ & 533 & 457 & 0.349 & 23.9 & 127 \\
\hline Rolls-Royce & $\begin{array}{l}\text { Model 250- } \\
\text { C47B/M }\end{array}$ & $\begin{array}{l}\text { Bell } 407 \text { (1) MD } \\
\text { Helicopter MD } \\
\text { 600N (1) }\end{array}$ & 485 & 447 & 0.355 & 23.4 & 124 \\
\hline Rolls-Royce & Gem 42-1 & $\begin{array}{l}\text { Agusta Westland } \\
\text { Lynx (2)Agusta } \\
\text { Westland A129 } \\
\text { Mangusta (2) }\end{array}$ & 746 & 664 & 0.310 & 26.8 & 183 \\
\hline Rolls-Royce & Model 250-B17F & $\begin{array}{l}\text { Groen Brothers } \\
\text { Aviation Hawk } 4 \\
\text { (1) O\&N Silver } \\
\text { Eagle (1) Soloy } \\
\text { Cessna 206 } \\
\text { 'Mark II' (1) }\end{array}$ & 336 & 336 & 0.373 & 22.3 & 98 \\
\hline
\end{tabular}

Annex 1/4. Most important manufacturers, types, technical data. [7]

\begin{tabular}{|c|c|c|c|c|c|c|c|}
\hline Manufacturer & Type of the engine & $\begin{array}{l}\text { Helicopter, in } \\
\text { which the en- } \\
\text { gine is built in }\end{array}$ & 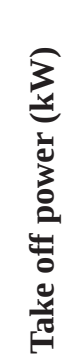 & 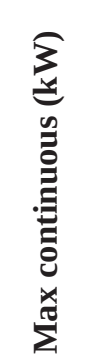 & 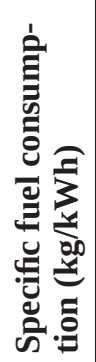 & 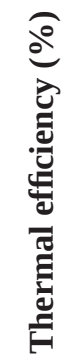 & 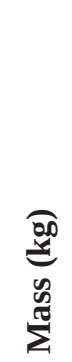 \\
\hline $\begin{array}{l}\text { Rolls-Royce } \\
\text { Turbomeca }\end{array}$ & RTM 322-01/8 & $\begin{array}{l}\text { AgustaWestland } \\
\text { Merlin HC HM } \\
\text { Mk1 }\end{array}$ & 1567 & 1374 & 0.276 & 30.2 & 254 \\
\hline $\begin{array}{l}\text { Rolls-Royce } \\
\text { Turbomeca }\end{array}$ & RTM 322-01/12 & $\begin{array}{l}\text { AgustaWestland } \\
\text { Apache AH Mk1 } \\
\text { (WAH64) }\end{array}$ & 1567 & 1374 & 0.276 & 30.2 & 250 \\
\hline
\end{tabular}




\begin{tabular}{|c|c|c|c|c|c|c|c|}
\hline Manufacturer & Type of the engine & $\begin{array}{l}\text { Helicopter, in } \\
\text { which the en- } \\
\text { gine is built in }\end{array}$ & 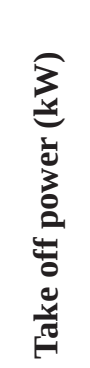 & 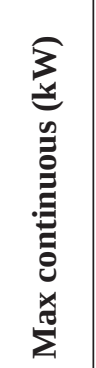 & 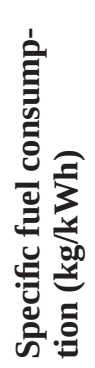 & 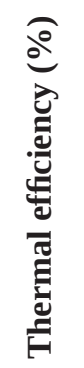 & 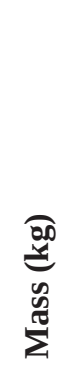 \\
\hline $\begin{array}{l}\text { Rolls-Royce } \\
\text { Turbomeca }\end{array}$ & RTM 322-02/8 & $\begin{array}{l}\text { AgustaWestland } \\
\text { Merlin HC Mk3 }\end{array}$ & 1688 & 1406 & 0.276 & 30.2 & 252 \\
\hline $\begin{array}{l}\text { Rolls-Royce } \\
\text { Turbomeca }\end{array}$ & RTM 322 Mk250 & $\begin{array}{l}\text { AgustaWestland } \\
\text { Merlin HC Mk3 }\end{array}$ & 1693 & 1491 & 0.276 & 30.2 & 255 \\
\hline $\begin{array}{l}\text { Rolls-Royce } \\
\text { Turbomeca }\end{array}$ & RTM 322-04/08 & $\begin{array}{l}\text { AgustaWestland } \\
\text { EH101 }\end{array}$ & 1950 & 1555 & 0.258 & 32.3 & 254 \\
\hline $\begin{array}{l}\text { Rolls-Royce } \\
\text { Turbomeca }\end{array}$ & RTM 322-01/9 & NHI NH90 (2) & 1799 & 1664 & 0.258 & 32.3 & 227 \\
\hline $\begin{array}{l}\text { Rolls-Royce } \\
\text { Turbomeca }\end{array}$ & RTM 322-01/9A & NHI NH90 (2) & 1905 & 1805 & 0.258 & 32.3 & 227 \\
\hline Rolls-Royce & AE 1007 & $\begin{array}{l}\text { Bell-Boeing V22 } \\
\text { Osprey (2) }\end{array}$ & 4549 & 3253 & 0.259 & 32.1 & 440 \\
\hline Turbomeca & Arrius 1A & $\begin{array}{l}\text { Eurocopter AS } \\
355 \text { N (2) }\end{array}$ & 340 & 296 & 0.338 & 24.7 & 114 \\
\hline Turbomeca & Arrius 1A1 & $\begin{array}{l}\text { Eurocopter AS } \\
355 \text { NP (2) }\end{array}$ & 343 & 305 & 0.338 & 24.7 & 114 \\
\hline Turbomeca & Arrius $1 \mathrm{M}$ & $\begin{array}{l}\text { Eurocopter AS } \\
555 \text { N (2) }\end{array}$ & 357 & 303 & 0.338 & 24.7 & 114 \\
\hline Turbomeca & Arrius 2F & $\begin{array}{l}\text { Eurocopter } \\
\text { EC120 (1) }\end{array}$ & 376 & 336 & 0.338 & 24.7 & 103 \\
\hline Turbomeca & Arrius 2B1 & $\begin{array}{l}\text { Eurocopter } \\
\text { EC135 t1 (2) }\end{array}$ & 421 & 348 & 0.320 & 26.0 & 114 \\
\hline Turbomeca & Arrius 2B1A-1 & $\begin{array}{l}\text { Eurocopter } \\
\text { EC135 t1 (2) }\end{array}$ & 463 & 414 & 0.320 & 260. & 114 \\
\hline Turbomeca & Arrius 2B2 & $\begin{array}{l}\text { Eurocopter } \\
\text { EC135 t2i (2) }\end{array}$ & 485 & 438 & 0.328 & 25.4 & 114 \\
\hline Turbomeca & Arrius 2K1 & $\begin{array}{l}\text { Agusta A109 } \\
\text { Power (2) }\end{array}$ & 500 & 425 & 0.320 & 26.0 & 115 \\
\hline Turbomeca & Arrius 2K2 & $\begin{array}{l}\text { Agusta A109 } \\
\text { LUH (2) }\end{array}$ & 534 & 454 & 0.321 & 26.0 & 115 \\
\hline Turbomeca & Arrius 2G1 & Ka 226t (2) & 537 & 427 & N/A & N/A & 115 \\
\hline Turbomeca & Arriel 1B & $\begin{array}{l}\text { Eurocopter AS } \\
350 \text { BA (1) }\end{array}$ & 478 & 441 & 0.362 & 23.0 & 114 \\
\hline Turbomeca & Arriel 1D & $\begin{array}{l}\text { Eurocopter AS } \\
350 \text { B1 (1) }\end{array}$ & 510 & 450 & N/A & N/A & N/A \\
\hline Turbomeca & Arriel 1D1 & $\begin{array}{l}\text { Eurocopter AS } \\
350 \text { B2 (1) }\end{array}$ & 546 & 466 & 0.352 & 23.6 & 122 \\
\hline
\end{tabular}




\begin{tabular}{|c|c|c|c|c|c|c|c|}
\hline Manufacturer & Type of the engine & $\begin{array}{l}\text { Helicopter, in } \\
\text { which the en- } \\
\text { gine is built in }\end{array}$ & 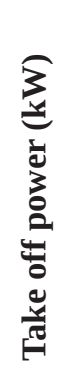 & 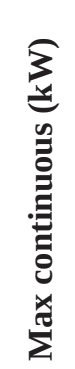 & 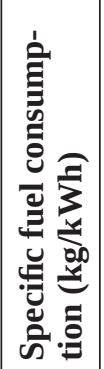 & 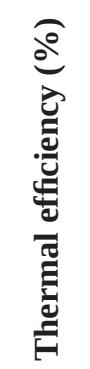 & 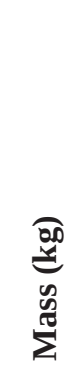 \\
\hline Turbomeca & Arriel 1C2 & $\begin{array}{l}\text { Eurocopter AS } \\
3652 \text { (2) } \\
\end{array}$ & 550 & 471 & 0.349 & 23.9 & 119 \\
\hline Turbomeca & Arriel 1M1 & $\begin{array}{l}\text { Eurocopter AS } \\
565 \text { Panther (2) }\end{array}$ & 558 & 487 & N/A & N/A & N/A \\
\hline Turbomeca & Arriel 1E2 & $\begin{array}{l}\text { Eurocopter EC } \\
145\end{array}$ & 550 & 516 & 0.349 & 23.9 & 125 \\
\hline Turbomeca & Arriel 1K2 & Agusta A 109 K & 550 & 471 & 0.349 & 23.9 & 123 \\
\hline Turbomeca & Arriel 1S1 & $\begin{array}{l}\text { Sikorsky S76 } \\
\text { A++ }\end{array}$ & 539 & 466 & 0.345 & 24.1 & 121 \\
\hline Turbomeca & Arriel 2B1 & $\begin{array}{l}\text { Eurocopter } \\
\text { AS350 B3(1)/EC } \\
\text { 130B4 }\end{array}$ & 632 & 544 & 0.333 & 25.0 & 119 \\
\hline Turbomeca & Arriel 2C & $\begin{array}{l}\text { Eurocopter AS } \\
365 \text { N3 }\end{array}$ & 635 & 597 & 0.333 & 25.0 & 128 \\
\hline Turbomeca & Arriel 2C2CG & $\begin{array}{l}\text { Eurocopter } \\
\text { HH65C (2) }\end{array}$ & 697 & 474 & N/A & N/A & 128 \\
\hline
\end{tabular}

Annex 1/5. Most important manufacturers, types, technical data. [7]

\begin{tabular}{|c|c|c|c|c|c|c|c|}
\hline $\begin{array}{l}\text { Manufac- } \\
\text { turer }\end{array}$ & $\begin{array}{l}\text { Type of the en- } \\
\text { gine }\end{array}$ & $\begin{array}{l}\text { Helicopter, in which } \\
\text { the engine is built in }\end{array}$ & 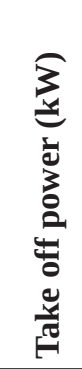 & 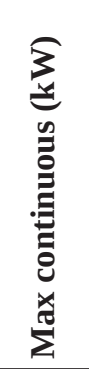 & 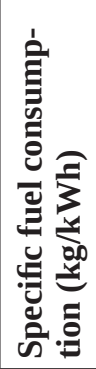 & 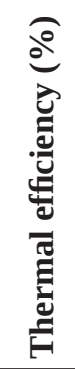 & 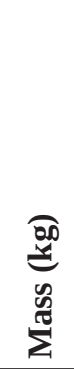 \\
\hline Turbomeca & Arriel 2C1 & Eurocopter EC155 B & 626 & 596 & 0.334 & 24.9 & 128 \\
\hline Turbomeca & Arriel 2S1 & Sikorsky S76 C+ & 638 & 587 & 0.329 & 25.4 & 128 \\
\hline Turbomeca & Arriel 2S2 & Sikorsky S76 C++ & 688 & 621 & N/A & N/A & N/A \\
\hline Turbomeca & TM 333 2M2 & $\begin{array}{l}\text { Cheetan (1)/Cheetal } \\
\text { (1) }\end{array}$ & 824 & 735 & N/A & N/A & N/A \\
\hline Turbomeca & TM 333 2B2 & DHRUV (2) & 824 & 735 & 0.315 & 26.5 & 166 \\
\hline Turbomeca & Ardiden $1 \mathrm{H} 1$ & DHRUV (2) & 1024 & 858 & 0.280 & 29.8 & N/A \\
\hline Turbomeca & Makila 1A & Eurocopter AS 332 & 1240 & 1130 & N/A & N/A & N/A \\
\hline
\end{tabular}




\begin{tabular}{|c|c|c|c|c|c|c|c|}
\hline $\begin{array}{l}\text { Manufac- } \\
\text { turer }\end{array}$ & $\begin{array}{l}\text { Type of the en- } \\
\text { gine }\end{array}$ & $\begin{array}{l}\text { Helicopter, in which } \\
\text { the engine is built in }\end{array}$ & 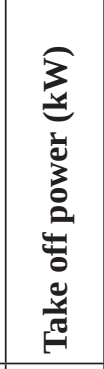 & 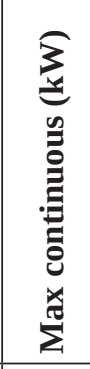 & 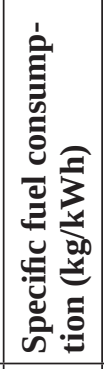 & 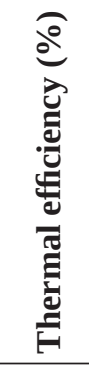 & 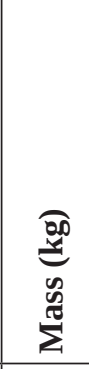 \\
\hline Turbomeca & Makila 1A1 & & 1357 & 884 & 0.294 & 28.3 & 235 \\
\hline Turbomeca & Makila 1A2 & $\begin{array}{l}\text { Eurocopter AS } \\
\text { 332MK2 (2)/ } \\
\text { AS532MK2 }\end{array}$ & 1376 & 1236 & 0.290 & 28.8 & 235 \\
\hline Turbomeca & Makila 2A & $\begin{array}{l}\text { Eurocopter EC 725/ } \\
\text { EC } 225 \text { (2) }\end{array}$ & 1564 & 1411 & 0.285 & 29.2 & N/A \\
\hline Turbomeca & Makila 2A1 & $\begin{array}{l}\text { Eurocopter EC 725/ } \\
\text { EC } 225 \text { (2) }\end{array}$ & 1567 & 1418 & N/A & N/A & N/A \\
\hline Turbomeca & Makila 1K2 & Denel Roivalk (2) & 1376 & 1236 & 0.290 & 28.8 & 235 \\
\hline Klimov & GTD 350 & Mi-2 & 298 & N/A & 0.489 & 17.0 & 135 \\
\hline Klimov & TV2-117 & Mi-8 & 1119 & N/A & 0.369 & 22.6 & 334 \\
\hline Klimov & TV3-1 & Mi-24A & 1659 & N/A & N/A & N/A & N/A \\
\hline Klimov & TV3-1 & Mi-14 & 1659 & N/A & N/A & N/A & N/A \\
\hline Klim & 7MT & $\mathrm{M}$ & 1659 & N/A & N/A & N/A & N/A \\
\hline Klimo & $\mathrm{T}$ & 27 & 1659 & N/A & N/A & N/A & N/A \\
\hline Klimov & TV3-117V & Mi-24 & 1566 & N/A & N/A & N/A & N/A \\
\hline Klimov & TV3-117VK & $\begin{array}{l}\text { Ka-27. Ka-29. } \\
\text { Ka-32 } \\
\end{array}$ & 1641 & N/A & N/A & N/A & N/A \\
\hline Klimov & TV3-117VM & Mi-8MT/Mi-17 & 1491 & N/A & N/A & N/A & N/A \\
\hline Klimov & TV3-117VMA & \begin{tabular}{|l} 
Ka-27. Ka-29. \\
Ka-31. Mi-24. \\
Mi-28A/N. Ka-32 \\
\end{tabular} & 1641 & N/A & 0.288 & 28.9 & 295 \\
\hline Klimov & VK-2500 I & $\begin{array}{l}\text { 8MT/Mi-17. Mi-24. } \\
\text { Mi-14. Ka-32. } \\
\text { Ka-50. Mi-28 }\end{array}$ & 1491 & N/A & 0.295 & 28.2 & 300 \\
\hline Klimov & VK-2500 II & $\begin{array}{l}\text { 8MT/Mi-17. Mi-24. } \\
\text { Mi-14. Ka-32. } \\
\text { Ka-50. Mi-28 }\end{array}$ & 1641 & N/A & 0.287 & 29.0 & 300 \\
\hline Klimov & VK-2500 II & $\begin{array}{l}\text { 8MT/Mi-17. Mi-24. } \\
\text { Mi-14. Ka-32. } \\
\text { Ka-50. Mi-28 } \\
\end{array}$ & 1790 & N/A & 0.282 & 29.6 & 300 \\
\hline Klimov & TV7-117V/VM & Mi-38 & 2088 & N/A & 0.295 & 28.2 & 360 \\
\hline Klimov & TV7-117VK & $\begin{array}{l}\text { Mi-28. Ka-50. } \\
\text { Ka-52 }\end{array}$ & 2088 & N/A & 0.308 & 27.0 & 380 \\
\hline Klimov & VK-800V & $\begin{array}{l}\text { Ansat. Mi-54. } \\
\text { Ka-126. Ka-226 }\end{array}$ & 597 & 447 & 0.390 & 21.3 & 140 \\
\hline
\end{tabular}




\begin{tabular}{|c|c|c|c|c|c|c|c|}
\hline $\begin{array}{l}\text { Manufac- } \\
\text { turer }\end{array}$ & $\begin{array}{l}\text { Type of the en- } \\
\text { gine }\end{array}$ & $\begin{array}{l}\text { Helicopter, in which } \\
\text { the engine is built in }\end{array}$ & 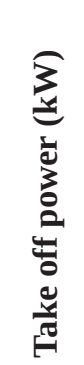 & 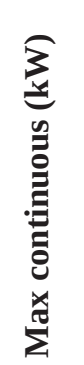 & 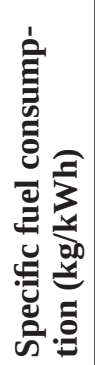 & 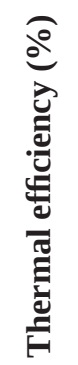 & 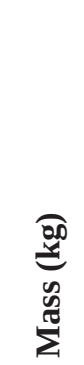 \\
\hline $\begin{array}{l}\text { Ivchenko- } \\
\text { Progress }\end{array}$ & D-136 & Mi-26. Mi-26T & 8501 & N/A & 0.266 & 31.4 & 1077 \\
\hline
\end{tabular}

